\title{
Crónica de una pandemia: confinamiento en Castelló de la Plana, España
}

\section{Crônica de uma pandemia: confinamento em Castelló de la Plana, Espanha}

\section{Chronicle of a pandemic: lockdown in Castelló de la Plana, Spain}

\author{
Reis Lloría Adanero \\ Universitat de València, València, España \\ Universitat Jaume I de Castelló, Castelló de la Plana, España \\ rlloria@uji.es
}

Resumen: Este artículo presenta los resultados de una investigación comenzada a raíz de la declaración del estado de alarma en España (Real Decreto [RD] No. 463/2020, de 14 de marzo) después que la Organización Mundial de la Salud (OMS) declarase la enfermedad por coronavirus 2019 (COVID-19) como pandemia el día 11 de marzo de 2020. Este decreto limitaba la libre circulación de las personas, así como el derecho de reunión, tanto en lugares públicos como privados, además de imponer la obligatoriedad de mantener una distancia de seguridad entre los individuos y la limitación del aforo en aquellos establecimientos que permanecían abiertos, entre otras medidas. Todo ello supuso un cambio en las rutinas diarias, pero también en el paisaje urbano, y despertó mi interés sobre la aceptación del estado de alarma y sus consecuencias. Para llevar a cabo la investigación, realicé cuatro entrevistas grupales (adolescentes, adultos jóvenes, mujeres y adultos, residentes en su mayoría en Castelló de la Plana, España) durante las semanas tercera y cuarta de confinamiento.

Palabras clave: Pandemia. Estado de alarma. Confinamiento. Rutinas. Fatiga digital. 
Resumo: Este artigo apresenta os resultados de uma pesquisa iniciada na esteira da declaração do estado de alarme na Espanha (Real Decreto [RD] No. 463/2020, de 14 de março) depois da Organização Mundial da Saúde (OMS) ter declarado a doença por coronavírus 2019 (COVID-19) uma pandemia em 11 de março de 2020. Esse decreto limitava a livre circulação das pessoas, bem como o direito de reunião, tanto em lugares públicos quanto privados, além de impor a obrigatoriedade de manter uma distância de segurança entre os indivíduos e a limitação da capacidade daqueles estabelecimentos que permaneceram abertos, entre outras medidas. Tudo isso pressupôs mudanças nas rotinas diárias, mas também na paisagem urbana, e despertou meu interesse na aceitação do estado de alarme e suas consequências. Para levar a pesquisa a cabo, realizei quatro entrevistas em grupo (adolescentes, jovens adultos, mulheres e adultos, em sua maioria residentes em Castelló de la Plana, Espanha) durante a terceira e a quarta semanas de confinamento.

Palavras-chave: Pandemia. Estado de alarme. Confinamento. Rotinas. Fadiga digital.

Abstract: This article presents the results of a study conducted following the decree of the state of alarm in Spain (Real Decreto [RD] No. 463/2020, enacted on March 14) after the World Health Organization (WHO) declared the coronavirus disease 2019 (COVID-19) as a pandemic on March 11, 2020. This decree limited the free movement of people, as well as the right of assembly, both in public and private places, in addition to imposing the obligation to maintain a safe distance between individuals and to limiting the capacity in those commercial establishments that remained open, among other measures. All this meant a change in daily routines, but also on the urban landscape, and aroused my interest in the acceptance of the state of alarm and its consequences. To carry out the research, I conducted four group interviews (adolescents, young adults, women, and adults, mostly residents of Castelló de la Plana, Spain) during the third and fourth weeks of the lockdown.

Keywords: Pandemic. State of alarm. Lockdown. Routines. Digital fatigue.

Data de recebimento: 08/10/2020

Data de aprovação: 05/02/2021 


\section{Introducción ${ }^{1}$}

El origen de esta comunicación se encuentra en la declaración del estado de alarma en marzo de 2020 como consecuencia de la declaración de pandemia provocada por la expansión del Coronavirus SARS CoV-2, por parte de la Organización Mundial de la Salud (OMS) y ante la falta de respuesta por parte de los gobiernos frente a la expansión de la enfermedad, la enfermedad por coronavirus 2019 (COVID-19).

El objetivo del Real Decreto (RD) No. 463/2020 (ESPAÑA, 2020a) era

[...] proteger la salud y seguridad de los ciudadanos, contener la progresión de la enfermedad y reforzar el sistema de salud pública. [...] Para hacer frente a esta situación, grave y excepcional, es indispensable proceder a la declaración del estado de alarma.

De acuerdo con el propio decreto,

[...] Las medidas [...] son imprescindibles para hacer frente a la situación, resultan proporcionadas a la extrema gravedad de la misma y no suponen la suspensión de ningún derecho fundamental, tal y como prevé el artículo 55 de la Constitución (ESPAÑA, 2020a).

Este decreto, con una duración inicial de 15 días, fue ampliado con 6 prórrogas sucesivas de la misma duración (ESPAÑA, 2020b, 2020c, 2020d, 2020e, 2020f, 2020g). El 28 de marzo el presidente del gobierno anuncia que entre los días 30 de marzo y 11 de abril se endurecían aún más las condiciones del anterior RD, mientras que en la cuarta prórroga (ESPAÑA, 2020e) se establecían las fases de la desescalada, es decir, las condiciones que se debían cumplir para ir progresando a lo que se ha dado en llamar "nueva

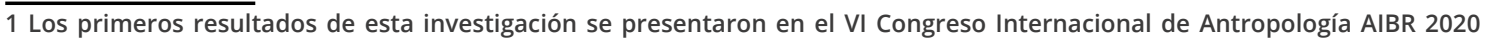
("Humanidades en Emergencia: Salud y Reconstrucción Social"). 
normalidad", que se alcanzó el día 21 de junio, último día en que estuvo en vigor este decreto y que ponía fin al estado de alarma. El artículo 7 del primer RD (ESPAÑA, 2020a) establece la "limitación de la libertad de circulación de las personas" y detalla los supuestos en que está permitido circular por la vía pública. El artículo 9, por su parte, establece las "medidas de contención en el ámbito educativo y de la formación", lo que resulta en la suspensión de la actividad educativa presencial en todos los niveles, tipos y centros, tanto públicos como privados, que pasa a modalidad a distancia y online (ESPAÑA, 2020a). En el artículo 10, por su parte, se establecen las "medidas de contención en el ámbito de la actividad comercial, equipamientos culturales, establecimientos y actividades recreativas, actividades de hostelería y restauración, y otras adicionales" y en el artículo 11, las "medidas de contención en relación con los lugares de culto y las ceremonias civiles y religiosas" (ESPAÑA, 2020a). En un anexo, se incorporaba una exhaustiva "Relación de equipamientos y actividades cuya apertura al público queda suspendida con arreglo a lo dispuesto en el artículo 10" (ESPAÑA, 2020a). Por último, el artículo 20 establece el régimen sancionador en caso del "incumplimiento o la resistencia a las órdenes de la autoridad competente" (ESPAÑA, 2020a).

El resultado del decreto de estado de alarma y sus sucesivas prórrogas fue el confinamiento de la población en sus domicilios, que podían abandonar únicamente para realizar aquellas actividades que el propio decreto estipulaba. Esto afectó de una manera total todos los ámbitos de la vida cotidiana y diaria de la población.

Dada la excepcionalidad de la situación, los objetivos de la investigación se han dirigido a conocer cómo se ha vivido, qué repercusiones ha tenido en la vida cotidiana el estado de alarma, así como la opinión sobre las medidas tomadas por el Gobierno de España para hacer frente a la pandemia.

Sin embargo, mi interés no venía sólo por conocer cómo se estaba viviendo la pandemia y el confinamiento resultante, sino también la percepción que había sobre el estado de alarma. Es 
decir, mi planteamiento se centraba sobre todo en conocer cómo se había aceptado la limitación de las libertades individuales que suponía el estado de alarma (libertad de movimientos y de reunión) de una forma tan rápida e incuestionada en general.

La pandemia ha provocado cambios sustanciales en la vida cotidiana de todos los individuos, siendo el decreto de estado de alarma el más visible de ellos, por la limitación de algunos de los derechos fundamentales, como ya se ha dicho (movimiento y reunión). Y como consecuencia de esta limitación de movimiento se produjo también la paralización de buena parte de la economía, todos aquellos sectores productivos considerados no esenciales se pararon. Por otro lado, también hizo su aparición el teletrabajo en algunos sectores en que su presencia todavía no era significativa, como vía para mantener algunas de esas actividades consideradas esenciales o aquellas que no requerían de presencialidad para continuar desarrollándose. Y ¿cómo afectaba ese cambio a las personas trabajadoras? ¿Cuál era la solución aportada por las empresas para un buen desarrollo del teletrabajo?

Como puede observarse, resulta muy difícil separar las consecuencias del decreto de estado de alarma de todos los aspectos de la vida cotidiana. El ámbito laboral y el educativo, el ámbito del ocio y la cultura, el ámbito de las relaciones sociales, se han visto comprometidos por el confinamiento.

Estas fueron las cuestiones que se plantearon para iniciar los debates: ¿Qué opinión tenían sobre las medidas tomadas por el gobierno para evitar la propagación de la pandemia? ¿Pensaban que se habían tomado en el momento adecuado? ¿Hubiera sido mejor decretar el estado de alarma más pronto? ¿Qué cambios se habían producido en la vida cotidiana a partir del momento en que se decretó el estado de alarma? ¿Cómo se habían visto afectadas las relaciones personales a causa del confinamiento?

Para ello, se realizaron 4 entrevistas grupales entre las semanas tercera y cuarta de confinamiento a personas residentes en su mayor parte en Castelló de la Plana, ciudad de aproximadamente 
175.000 habitantes. Una de las entrevistas fue con 6 adolescentes deportistas, estudiantes de Enseñanza Secundaria Obligatoria residentes en Castelló de la Plana, Borriol y Sagunt, con una edad entre 14 y 16 años. También se entrevistó a un grupo de adultos jóvenes, entre 21 y 29 años, formado por 3 hombres y 4 mujeres ( 2 estudiantes, 1 persona parada, 1 en Expediente de Regulación Temporal de Empleo [ERTE] y 3 trabajando), y 2 grupos de personas adultas, uno formado por mujeres pertenecientes a una asociación feminista y de izquierdas (entre 50 y 70 años) y el segundo por un grupo de exalumnos del mismo centro educativo, 4 hombres y 1 mujer, con diferentes perfiles profesionales (empleados, funcionarios y profesional liberal), de 55 años. Todas las entrevistas fueron realizadas por videoconferencia. Además, se ha hecho un seguimiento de la prensa diaria y una recopilación de diferentes mensajes recibidos a través de las redes sociales, muy activas durante todo el período de confinamiento. Y, por supuesto, una observación atenta de todo aquello que ocurría en el barrio durante mis desplazamientos para realizar aquellas actividades permitidas por el decreto de estado de alarma.

Quiero destacar aquí que el interés no era tanto cómo vivía la pandemia y el decreto de estado de alarma la población en general, sino la gente más próxima a mí, razón por la cual todos los grupos estaban formados por personas que podían conocerse entre ellas y a las que yo, en mayor o menor medida, también conocía. Por último, cabe señalar que se trata de un estudio exploratorio en el inicio de la investigación que está previsto que continúe.

\section{Los días previos a la declaración del estado de alarma}

Como ya se ha dicho en la introducción, la declaración del estado de alarma entró en vigor el día 14 de marzo, pero fue una medida que se anunció unos días antes. Es importante destacarlo porque se produjeron escenas en los supermercados que generaron sorpresa y tuvieron una fuerte repercusión en los 
Crónica de una pandemia: confinamiento en Castelló de la Plana, España Reis Lloría Adanero

medios de comunicación y dieron pie a numerosos comentarios y memes, jocosos o irónicos, en las redes sociales.

El día 14 de marzo era sábado y los dos días anteriores, jueves y viernes, ante la perspectiva de no poder salir de casa y el miedo a un posible desabastecimiento de productos de primera necesidad, los supermercados y tiendas de alimentación se vieron desbordados por el alud de personas que acudieron. Esto hizo que desaparecieran de los lineales productos de primera necesidad, tanto de alimentación (pasta, arroz, legumbres, fruta y verdura, carne...) como de higiene y limpieza (papel higiénico, pañuelos de papel, alcohol, gel hidroalcohólico, guantes, lejía...) (figuras 1 y 2). Las colas que se formaron tanto para acceder como en el interior de los establecimientos (mostradores de productos frescos o en las cajas) eran algo que no se había visto con anterioridad en este país.

Figura 1. Lineal de legumbres y nevera de verduras ${ }^{2}$

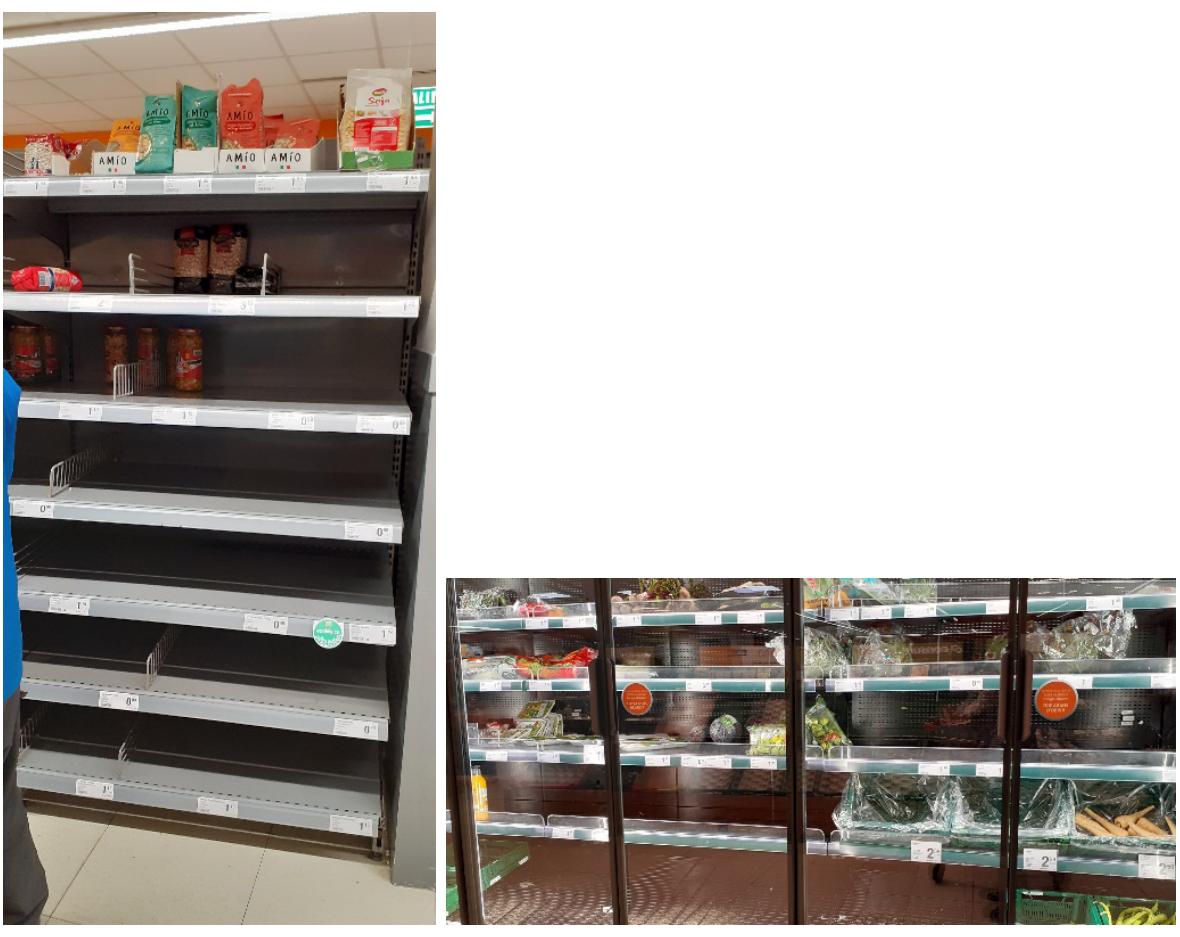

Fuente: Fotografías tomadas los días 12 y 13 de marzo de $2020^{3}$.

2 Si no se indica otra cosa, las fotografías fueron tomadas en un supermercado de la cadena Consum. 3 Si no se indica lo contrario, las fotografías son propias y están tomadas en Castelló de la Plana. 
Crónica de una pandemia: confinamiento en Castelló de la Plana, España

Figura 2. Lineal de papel higiénico

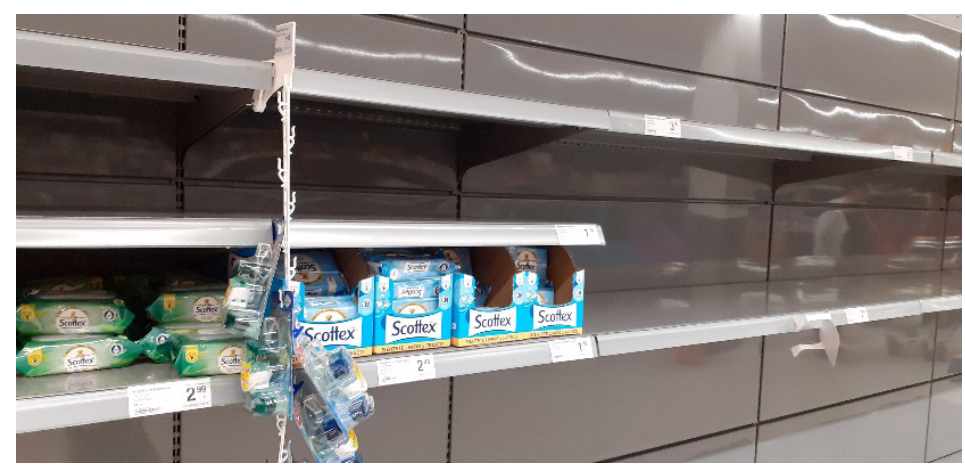

Fuente: Fotografía tomada el día 13 de marzo de 2020.

Estas compras en los días previos dieron lugar a un cierto desabastecimiento en los días posteriores por las dificultades para reponer los productos (producción, transporte y distribución) y, también, a numerosos mensajes en redes sociales, en los que se ridiculizaba o cuestionaba estos comportamientos (Figura 3).

Figura 3. Mensajes en redes sociales ${ }^{4}$

8

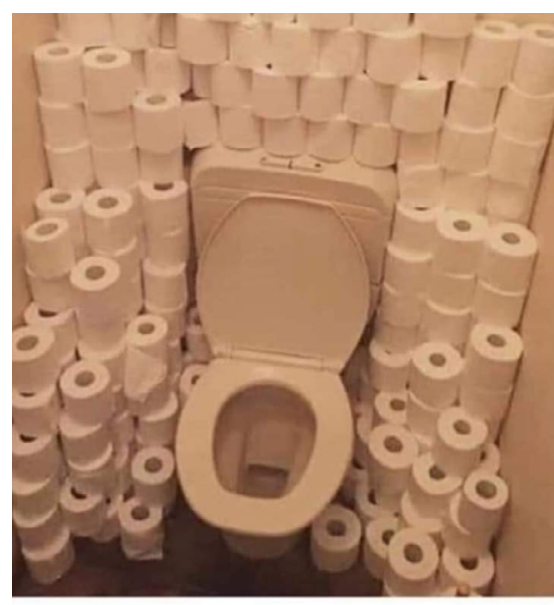

EL BAÑO DE LOS QUE HAN LLEGADO PRONTO A MERCADONA
A los que compran 30 jabones y dejan los estantes vacíos para los demás.

¿sabía que para protegerse del Coronavirus necesita que las demás personas también se laven las manos?

Fuente: Colección personal de la autora.

4 Mercadona es la primera cadena de supermercados en España. 


\section{Vida cotidiana durante el estado de alarma o cuando tener perro es considerado como un privilegio}

Una vez decretado el estado de alarma se produjo el confinamiento de la población, hecho que afectó profundamente la vida cotidiana en todos los aspectos: convivencia, horarios, tareas del hogar, tareas de cuidados, trabajo y estudio, ocio y tiempo libre.

La principal cuestión que se planteaba era, pues, cómo se vivía esa excepcionalidad y qué cambios se habían producido en la organización de la vida y del espacio doméstico. Una de las cosas a tener en cuenta es el hecho que la docencia presencial desaparece y se recomienda el teletrabajo en aquellas actividades en que es posible, de la misma manera que el tiempo libre debe pasarse también en casa, por lo que el domicilio particular debe transformarse en lo que Fontana Sierra (2020) etiqueta como "espacio multidisciplinar", un espacio polivalente en el que integrar las actividades de toda la familia (Figura 4).

Figura 4. Comedor preparado para el teletrabajo

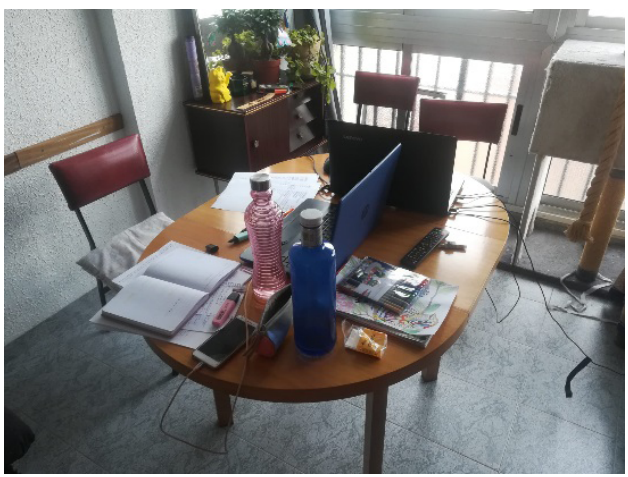

Fuente: Fotografía cedida por uno de los participantes en las entrevistas.

En este sentido, aquello que más se destaca en las entrevistas es la prohibición de salir a la calle si no es por una causa justificada, al mismo tiempo que se considera una medida necesaria si se quiere controlar la propagación de la enfermedad. Es entre los 
adolescentes donde se percibe una crítica más fuerte y esto por dos razones. En primer lugar, se trata de menores de edad, estudiantes de Enseñanza Secundaria Obligatoria que han visto cómo las clases presenciales se suspendían y, además, se trata de deportistas, acostumbrados a entrenar diversos días a la semana y a jugar sus partidos el fin de semana y, de repente, estas actividades también se suspenden. $Y$ en segundo lugar, no tienen motivo justificado para salir (ir al trabajo, a comprar o a hacer gestiones, por ejemplo).

\begin{abstract}
Yo estoy acostumbrado a hacer deporte casi todos los días, ahora en casa me da pateo hacer deporte, ¿para qué te voy a engañar? Pero, yo que sé, estaría bien que pusieran una medida... Por ejemplo, la gente que hace muchas horas de deporte a la semana y lleva años practicando deporte, pues que le dejaran salir a correr una vez a la semana o algo así, aunque sea media hora, o que pudiera salir de casa a hacer deporte, corriendo veinte minutitos o lo que sea, y ya después haces deporte en tu casa, ¿sabes? Pero que te dejen salir. (Entrevista adolescentes).
\end{abstract}

\title{
10
}

En general se aprecia una aceptación del confinamiento como una cuestión relacionada con el bien común, como única vía conocida y posible, por el momento, para contener la expansión de la COVID-19. Aquí, sin embargo, se pueden ver diferentes maneras de acatar el decreto, es decir, tomándolo al pie de la letra y saliendo solo si es estrictamente necesario y siempre buscando aquellos establecimientos más próximos al hogar, y aquellas personas que, acatando la idea general del decreto, lo interpretan de una manera más laxa y, cuando tienen necesidad de salir, aprovechan para hacer un recorrido más largo de lo que sería necesario para estar más tiempo en la calle, al tiempo que se excusan considerando que es la práctica habitual.

No he salido, desde el primer día que estoy encerrada en casa y no he salido ningún día. (Entrevista mujeres). 
Crónica de una pandemia: confinamiento en Castelló de la Plana, España Reis Lloría Adanero

Después, como haréis todos, me bajo a comprar el pan, me bajo a comprar esto, me bajo a comprar lo otro... Procuro irme lo más lejos posible para pasear un ratito más y ya está, no hago más cosas. (Entrevista adultos).

Una de las actividades que una interpretación del decreto de alarma permitía era sacar a los animales domésticos (Figura 5). Esto dio pie a numerosos mensajes en redes sociales (Figura 6) y a que, de alguna manera, se considerara tener perro como "un privilegio" (Entrevista jóvenes).

Figura 5. Documento sobre preguntas frecuentas: apartado dedicado a los derechos de los animales

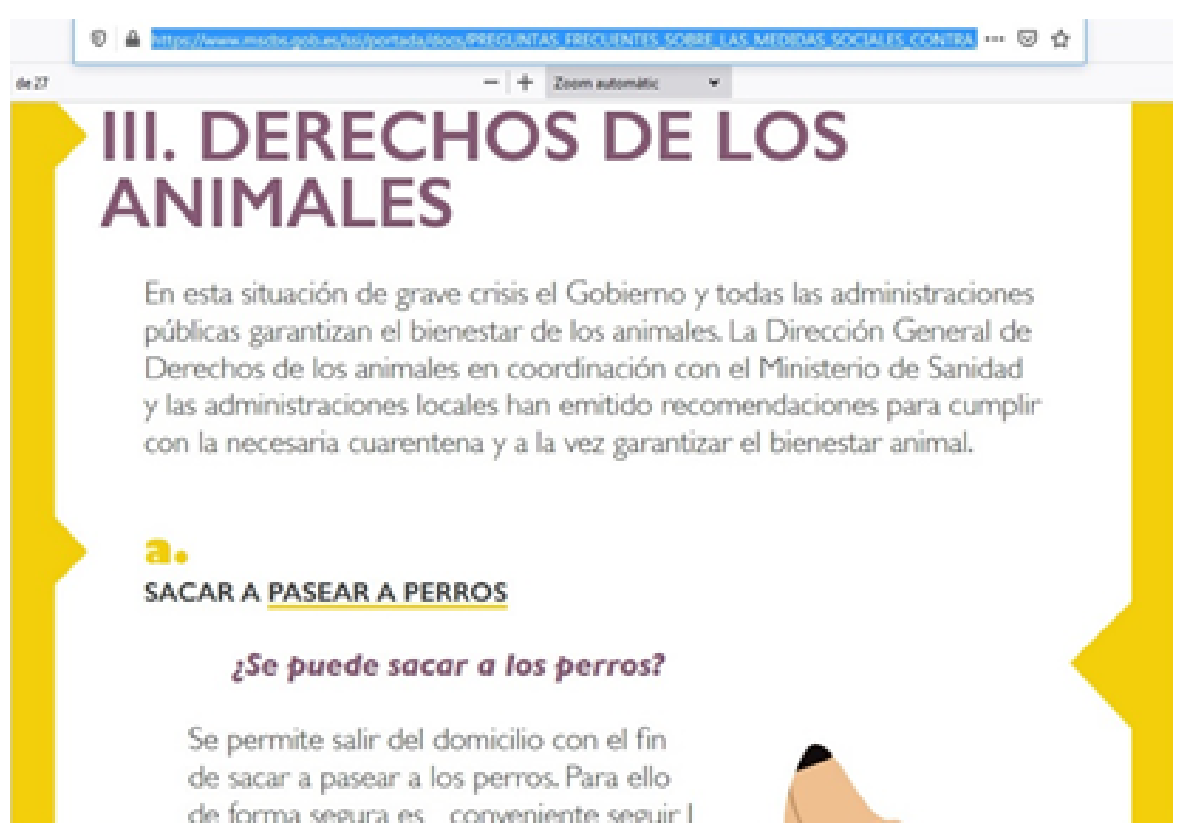

Fuente: Ministerio de Derechos Sociales y Agenda 2030 (2020). 


\section{Figura 6. Chistes en redes sociales relacionados con el paseo de mascotas}
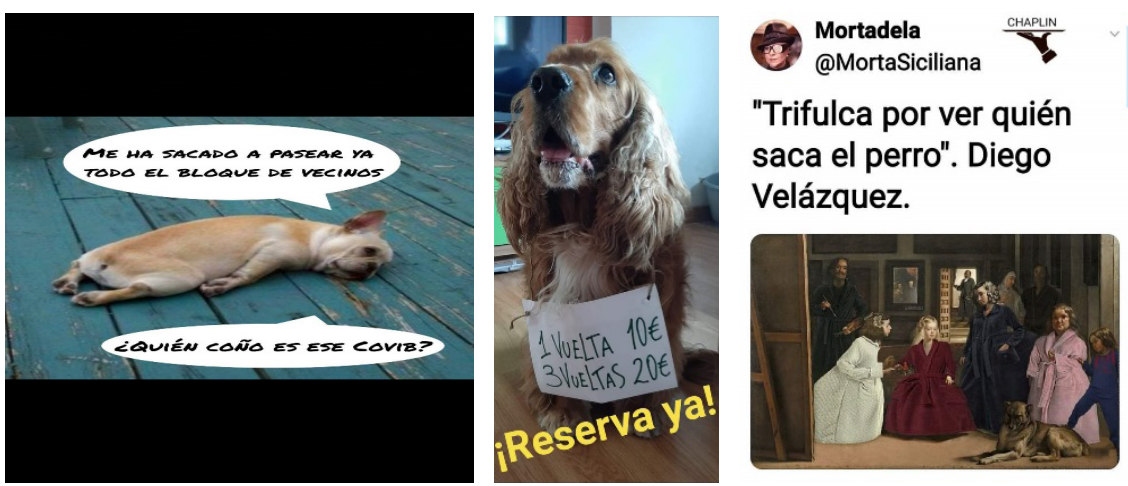

Fuente: Colección personal de la autora.

Uno de los aspectos comentados durante las entrevistas estaba relacionado con las características de la vivienda. En este sentido se destaca que las dimensiones, la orientación, disponer o no de balcón o terraza también influyen en la salud:

Nosotros estamos en 70 metros, con un baño y somos dos con dos gatas. Sin patio, sin balcón. Y apuntando todo al norte, o sea que no nos da el sol ni de... Creo que me voy a poner malo por falta de vitamina $\mathrm{D}$ o algo. (Entrevista jóvenes).

Las tareas domésticas ocupan una parte del tiempo de las personas adultas y jóvenes, destacando el hecho que ha aumentado debido al mayor número de horas que se pasa en casa. Entre las personas jóvenes hay un reparto equitativo de las tareas y dedican el mismo tiempo los dos miembros de la pareja. Además, las tareas domésticas, en algún caso, se han convertido en una forma de ocupar el tiempo.

Yo estoy en el paro y ama de casa, así que sigo trabajando y aún más, porque al estar todos en casa, se ensucia todo mucho más, se cocina todo mucho más, porque no vamos a comer a casa de nadie. (Entrevista jóvenes). 
Tenemos los mismos horarios y todo, entonces, en fin de semana es dos horas tú por un lado limpias y yo por otro, limpio. (Entrevista jóvenes).

Pero, bueno, ¡los armarios están! ¡Estoy dejándolos [...]! (Entrevista adultos).

Respecto al trabajo encontramos todas las situaciones posibles: teletrabajo, trabajo presencial, en situación de ERTE, sin actividad porque se incluye en los sectores explícitamente prohibidos por el decreto de estado de alarma, y jubiladas. Entre aquellas personas que trabajan presencialmente se destaca la falta de medidas de prevención y protección por parte de las empresas y el estrés que esa situación provoca por el riesgo de contagio.

La semana que viene vuelvo a trabajar y estoy asustada, porque dicen que sí, que todo... Pero mi trabajo, mi oficina concretamente, medios no se han puesto, no hay mamparas, no hay guantes, no hay mascarillas. Yo, por ejemplo, hoy, después de diez o nueve días, es la primera vez que he salido, sí que he visto todas las cajeras de supermercados, farmacias a donde he ido hoy, que sí que tienen unas mamparas de metacrilato, y mi empresa no ha sido capaz de poner ni un plástico ni nada. Eso me preocupa mucho y me angustia un poco volver. (Entrevista mujeres).

En este sentido, se ha podido observar que los diferentes establecimientos han instalado mamparas de separación, de distintos materiales y calidades (Figura 7). 
Figura 7. Mamparas instaladas para proteger de posibles contagios en un supermercado, un quiosco y una farmacia de la localidad
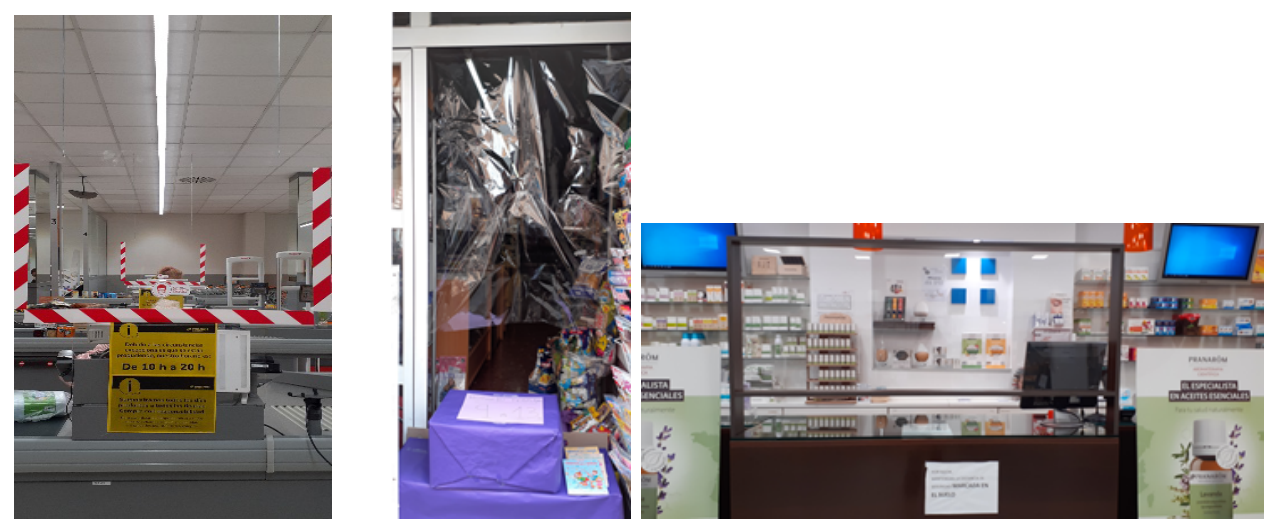

Fuente: Fotografías realizadas los días 27 y 28 de marzo y 2 de abril de 2020.

Otra crítica importante viene de las personas que se encuentran trabajando desde casa. En este caso se hace especial hincapié en la falta de medios. Tanto ordenadores como mobiliario y conexión a internet son aportados, en su mayor parte, por personas trabajadoras, lo que permite hacer una reflexión sobre la rápida implantación del teletrabajo durante esta pandemia que se alargará en el tiempo porque económicamente resulta más ventajoso para las empresas. Al mismo tiempo, también se pone de manifiesto las dificultades que pueden aparecer por las malas conexiones a internet, en función del lugar de residencia, así como por la necesidad de aumentar los gigas contratados para poder hacer frente a las necesidades de conexión diaria, cuando las conexiones personales están destinadas a un uso principalmente lúdico, sobre todo en el grupo de jóvenes. Otro aspecto relevante tiene que ver con la necesidad de adaptarse a la virtualidad laboral. Por un lado, reuniones virtuales a través de diferentes plataformas para organizar el trabajo diario y mantener el contacto con la empresa y, por otro, los problemas que pueden derivarse de la calidad de las conexiones (Figura 8). 


\section{Figura 8. Teletrabajo desde casa y dificultades en las conexiones}
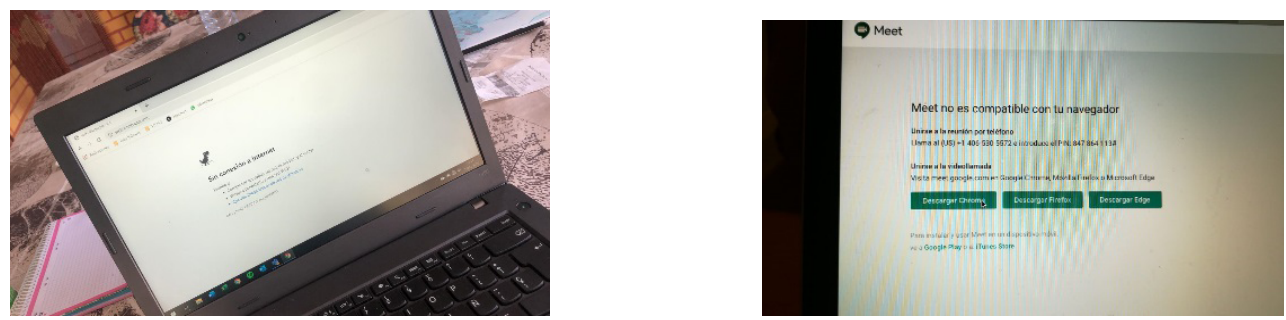

Fuente: Fotografías cedidas por participantes en las entrevistas.

Y ahora estamos trabajando desde casa, el Teams, en el Skype, pues hacemos la reunión por la mañana de qué vamos a hacer. Más o menos vemos a quién podemos llamar, a quién no, porque están cerrándolo todo y no hay de nada. (Comercial importación-exportación de frutas). (Entrevista jóvenes).

Y todo, pues, todas las, cualquier cosa tenemos Skype, tenemos Teams... Hay que sobrellevarlo como se puede, porque, pues a veces cae la red, a veces hay problemas de conexión; el trabajo, obviamente, ya no es lo que era, pero, bueno... (Ingeniera en una empresa multinacional). (Entrevista jóvenes).

La aparición del teletrabajo como forma de continuar con la actividad económica sirve también para hacer una crítica a la situación laboral, tanto la incertidumbre generada por la pandemia como por la precariedad propia del mercado laboral en España.

Lo de ahora, lo del teletrabajo y todo eso, ahora porque el sistema no está preparado porque... Y, además, nosotros lo estamos haciendo en casa con nuestros medios, o sea, mi $A D S L$, mi ordenador, todo. Lo que pasa es lo que decimos, que, claro, frente a lo que viene, cualquiera dice "no, no, no" y se pone exquisito o me... O sea, pues tira adelante y mira, lo que venga... Porque yo pienso que si yo estoy preparada para el teletrabajo, caeré más tarde que uno que no está preparado para el teletrabajo. (Entrevista mujeres). 
El sistema educativo es uno de los ámbitos que se ha tenido que adaptar a la virtualidad, por tratarse de una de las actividades consideradas esenciales pero que no podía hacerse presencial desde el momento en el que se decretó el estado de alarma. Tanto estudiantes como profesorado en todos los niveles educativos tuvieron que adaptarse de hoy para mañana a la virtualidad para poder continuar el curso y no perderlo. El RD No. 463/2020 (ESPAÑA, 2020a) decretaba el estado de alarma durante 15 días, pero fue prorrogado por el RD No. 476/2020 (ESPAÑA, 2020b) por otros 15 días. En el momento de hacer las entrevistas sólo se había decretado una prórroga, aunque la evolución de la pandemia ya permitía adivinar que habría más, por lo que la continuidad del curso presencial se daba por concluida, pasando a ser virtual. Sin embargo, la falta de información oficial provocaba cierta ansiedad, tanto a estudiantes como a docentes. Profesorado y estudiantado de primaria, secundaria y universidad tuvieron que adaptarse a la docencia en línea con sus propios recursos y con los conocimientos que tuvieran hasta ese momento. Esto ha puesto de manifiesto la existencia de una importante brecha digital, principalmente entre el alumnado, tanto por zonas geográficas, como por clase social, lo que ha obligado a la administración a intentar paliarlo proporcionando tabletas con conexión a internet -14.000 ha prestado la Conselleria de Educación de la Generalitat Valenciana (GENERALITAT VALENCIANA, 2020)-, pero también el profesorado ha tenido que adaptarse a la realidad de su alumnado: grupos de Whatsapp, correo electrónico, llamadas telefónicas...

\footnotetext{
A nivel de faena, hemos empezado a hacer el teletrabajo, a reunirnos, hoy mismo, para enviar actividades a los niños. (Entrevista mujeres).
}

El grupo de adolescentes estaba formado por alumnos de diferentes centros de secundaria. En él se podía apreciar un discurso claro relacionado con el exceso de tareas que se les exigían. La dinámica variaba de un centro a otro, en algunos 
había clases virtuales y en otros no, pero en todos los casos se mandaban deberes. Y la incertidumbre se mostraba claramente en referencia a la evaluación. El curso académico en primaria y en secundaria está dividido en tres trimestres. El segundo trimestre había finalizado justo la semana en que se decretó el estado de alarma y comenzaba en ese momento el tercer trimestre. La duda que se les planteaba era cómo iba a evaluarse ese tercer trimestre si no volvían al aula presencial. La docencia virtual en muchos casos pasaba únicamente por subir ejercicios y videos tutoriales al aula virtual. Estos ejercicios se debían subir resueltos o remitir por correo electrónico al profesorado, sin ningún tipo de contacto de otra clase. No fue hasta el 8 de mayo de 2020 que se publicó en el Diari Oficial de la Generalitat Valenciana una resolución de la Secretaría Autonómica de Educación y Formación Profesional "por la que se establecen el marco y las directrices de actuación que hay que desarrollar durante el tercer trimestre del curso 2019/2020 y el inicio del curso 2020/2021, ante la situación de crisis ocasionada por la Covid-19", esto es, casi dos meses después de decretarse el estado de alarma. En esta resolución, se establece que la docencia se debe adaptar a las circunstancias, así como flexibilizar el currículum y las programaciones didácticas y adaptar la evaluación, la promoción y la titulación.

Y hay profesores que empiezan a enviar deberes, pero no tienen en cuenta que tenemos doce asignaturas más y aunque no podamos salir de casa, también necesitamos levantarnos, y no podemos estar todo el día de cara al ordenador. Yo pienso que es hasta que se regule un poco y los profesores pillen el truco y digan "bueno, pues esta cantidad de deberes está bien". Y no pongan una cantidad pensando que está bien, pero igual es una locura. (Entrevista adolescentes).

Y que se pongan de acuerdo para trabajar todos en una misma plataforma. Porque igual hay un profesor que te dice "vamos a hacer clase por videoconferencia en Zoom" y hay otro que se va 
a otra plataforma y vamos locos, yo por lo menos. (Entrevista adolescentes).

También la docencia universitaria se vio afectada y las clases pasaron a ser virtuales. Aquí se vieron afectados de diferente manera según el curso y el grado que estuvieran realizando. Y de nuevo aparece la duda respecto a la forma de evaluar las asignaturas, las prácticas y el trabajo final de grado (TFG). No fue hasta el 2 de abril que se publicó la noticia de la suspensión definitiva de las clases presenciales en la universidad a causa de la imprevisible evolución de la pandemia.

La semana de Magdalena todavía no nos mandaron faena ni dan nada, entonces era un poco más vacaciones, pero esta semana ya hemos empezado clases online, que de tres, bueno, cuatro asignaturas que tenemos este cuatrimestre, dos tenemos clases online en el horario de siempre, de clase como hasta ahora, y de las otras pues nos han dicho, como nos suben los apuntes en el aula virtual, entonces nos apañamos nosotros con eso, con la teoría y luego los problemas. (Entrevista jóvenes).

Como estudio Medicina, todos los médicos están en el hospital todo el día, entonces, todavía no nos han dado materia. Algunos profesores aún nos suben algo, pero de momento el único mensaje que nos han dado es que nos tenemos que buscar un poco la vida, es decir, investigar nosotros, y tener paciencia. Y supongo que nos examinarán igualmente de todo, pero no sabemos cómo van a hacerlo. (Entrevista jóvenes).

Hay algunos TFGs que eran experimentales, también de ir al laboratorio a hacer las pruebas o lo que fuera, $y$ tampoco pueden hacer nada. $Y$ es que es el TFG, o sea, sin el TFG no acaban la carrera, o sea de exámenes y de los TFGs y eso no nos han dicho nada. De momento, como que las clases online para pasar este mes o lo... Y supongo que los otros que viene también, pero de momento no nos dicho nada, así que... (Entrevista jóvenes). 
Crónica de una pandemia: confinamiento en Castelló de la Plana, España

Otro aspecto que también se puso de relieve en las entrevistas estaba relacionado con el tiempo libre. ¿Cómo se ocupa el tiempo libre cuando no se puede salir a la calle? Desde el inicio del estado de alarma aparecieron en las redes sociales numerosas propuestas de actividades, de todo tipo y para todas las edades: jeroglíficos hechos con emojis, enlaces para visitas virtuales a museos, fondos de diferentes bibliotecas, colegios profesionales que proponían actividades o recomendaciones para pasar la cuarentena de la mejor manera posible, enlaces a videos con rutinas de ejercicios, cocina, manualidades, etc.

Figura 9. Jeroglíficos que circularon por redes sociales los primeros días (izquierda) y enlace a la biblioteca de la UNESCO

\section{9}

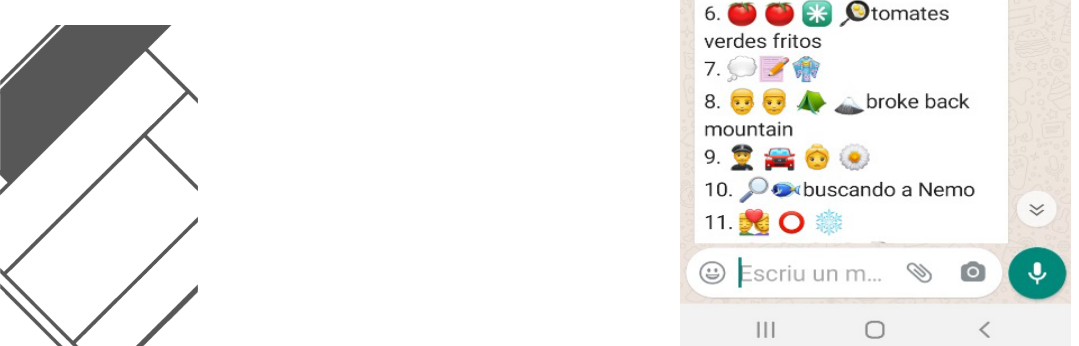

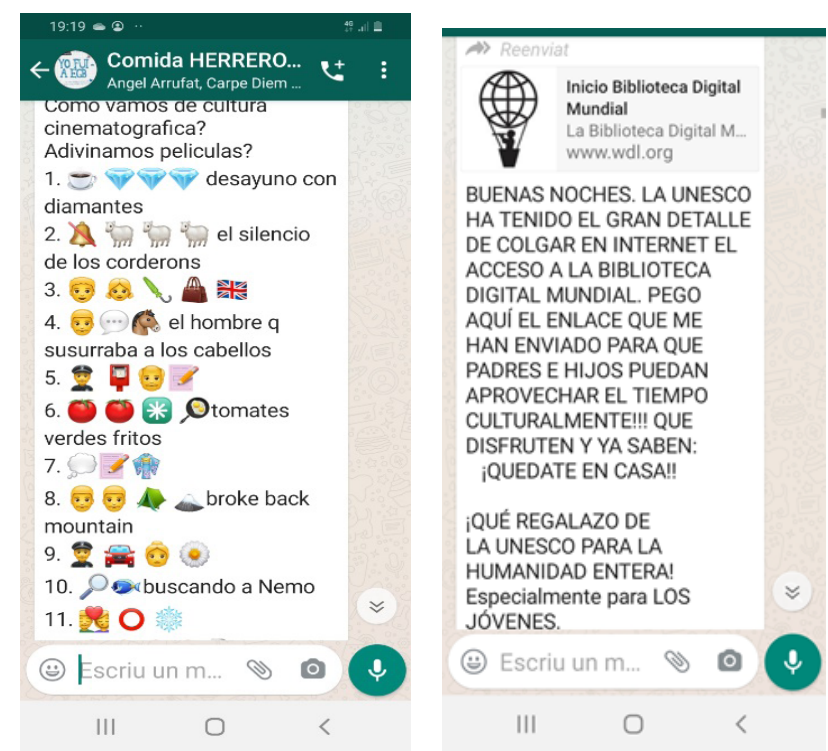

Fuente: Colección personal de la autora. 
Crónica de una pandemia: confinamiento en Castelló de la Plana, España Reis Lloría Adanero

Figura 10. Recomendaciones psicológicas y propuestas de actividades que circularon por redes sociales

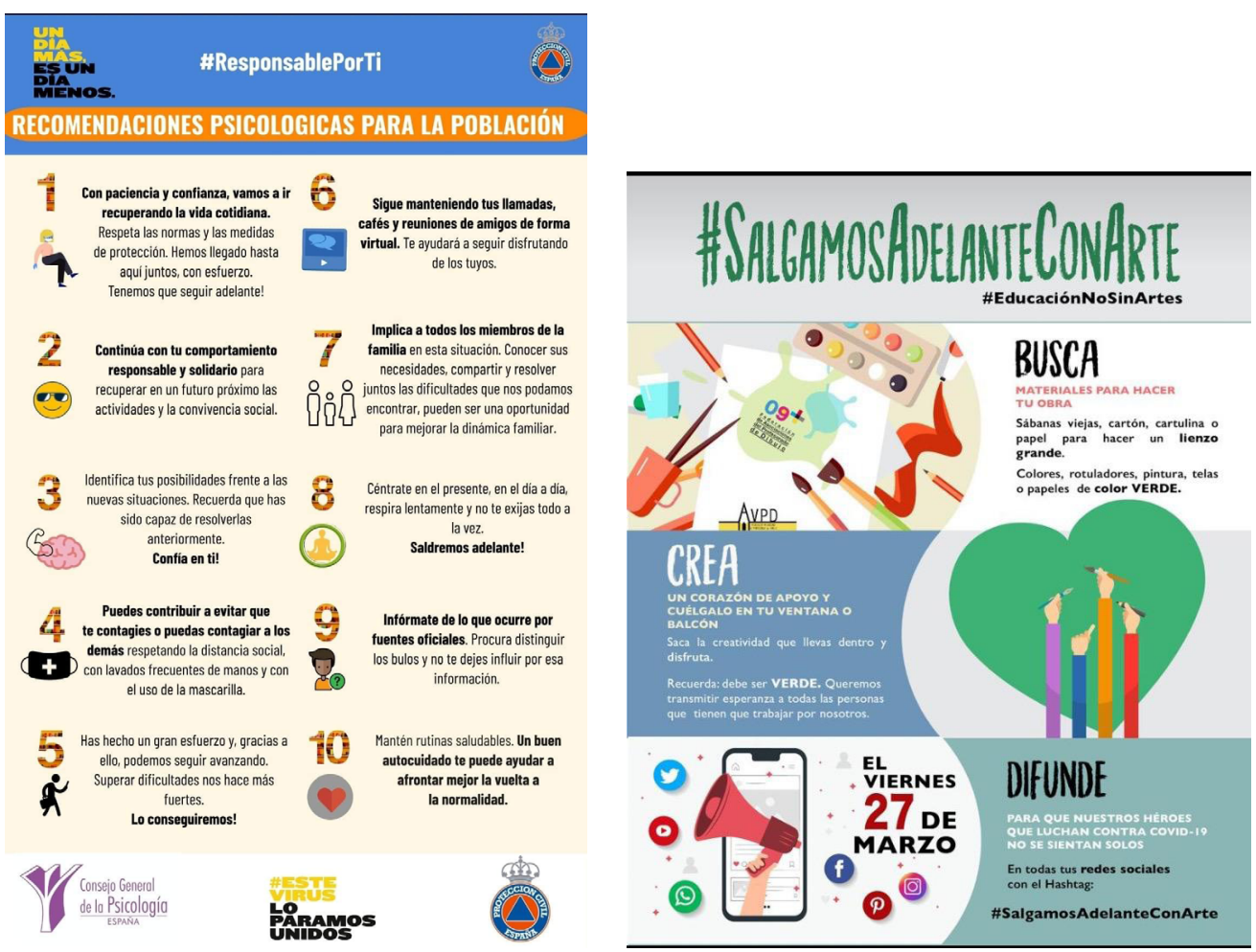

En el grupo de adolescentes aparecen críticas al decreto porque no se les permitía salir. Acostumbrados como estaban a practicar deporte casi todos los días de la semana, estar encerrados en casa se les hacía muy difícil. Habitualmente la mayor parte del tiempo libre, además de hacer rutinas de ejercicio físico, lo dedican a jugar a la play, tanto a nivel individual como en línea, una vía para mantener el contacto con sus amistades.

Yo hablo con todo el mundo. Y hablar con la gente que si no, en casa sin hacer nada, al final me aburre, hay que preocuparse por los amigos de verdad, y preguntar qué es de su vida. Y yo qué sé, alguna videollamada, jugar a la play. No perder el contacto, al final... (Entrevista adolescentes). 
En los grupos de personas jóvenes y de personas adultas había una mayor variedad de actividades para pasar el tiempo libre. Además de hacer ejercicio dentro de casa, se destinaba parte del tiempo a la televisión, arreglar la casa, cocinar, hacer ejercicio, y una actividad común en los grupos de personas jóvenes y adultas es la lectura. $Y$ en todos los casos se destaca que todas esas cosas se hacen porque se dispone de tiempo extra. El estado de alarma hace bajar el ritmo laboral, tampoco hay desplazamientos al lugar de estudio o de trabajo, por lo tanto, se dispone de más tiempo libre que se ha de ocupar de alguna manera. La televisión de pago ha sido también una alternativa de ocio. También se destaca que el mantenerse ocupado ayuda a superar mejor el confinamiento.

Yo tenía veinte mangas en palanca y me he leído ya doce. (Entrevista jóvenes).

Yo creo que lo que he aprovechado mucho es para leer libros que quería, que me apetecía, pero eran demasiado largos y no me daba tiempo, y ahora, por ejemplo, me los estoy haciendo. (Entrevista jóvenes).

Pues yo estoy leyendo muchísimo, cuando no estoy trabajando y como tengo más horas, me parece, que el resto. Estoy aprendiendo a cocinar un poquito más. (Entrevista adultos).

Ordenar armarios, libros y fotos, básicamente. Y ahora que puedo, estoy leyendo un poquito más. (Entrevista adultos).

Pues no lo llevo mal porque busco hacer cosas. O sea, ahora mismo estoy limpiando un estantería que tengo llena, saturada de libros que cualquier día explotará y nunca tenía tiempo. A veces me gusta cocinar por cocinar, por hacer algo, mirar la tele e intento hacer algo de ejercicio. Eso sí que es importante porque si no de esta saldré con no sé cuántos quilos más, redonda que no podré salir por la puerta. (Entrevista mujeres). 
Esta última cita recoge una idea que ha circulado por las redes sociales durante la pandemia, con imágenes de obras de arte conocidas transformadas a raíz de la cuarentena, así como chistes relativos al aumento de peso por la falta de ejercicio (Figura 11). Como pone de manifiesto Spregelburd (2020, p. 104), "la pandemia ha sido fuente de obras de humor inagotables", para quien "el meme logra a veces mayor contundencia informativa y polémica que la noticia", además de ser un "humor anónimo, planetario".

Figura 11. Memes sobre el sobrepeso por la falta de ejercicio durante el confinamiento
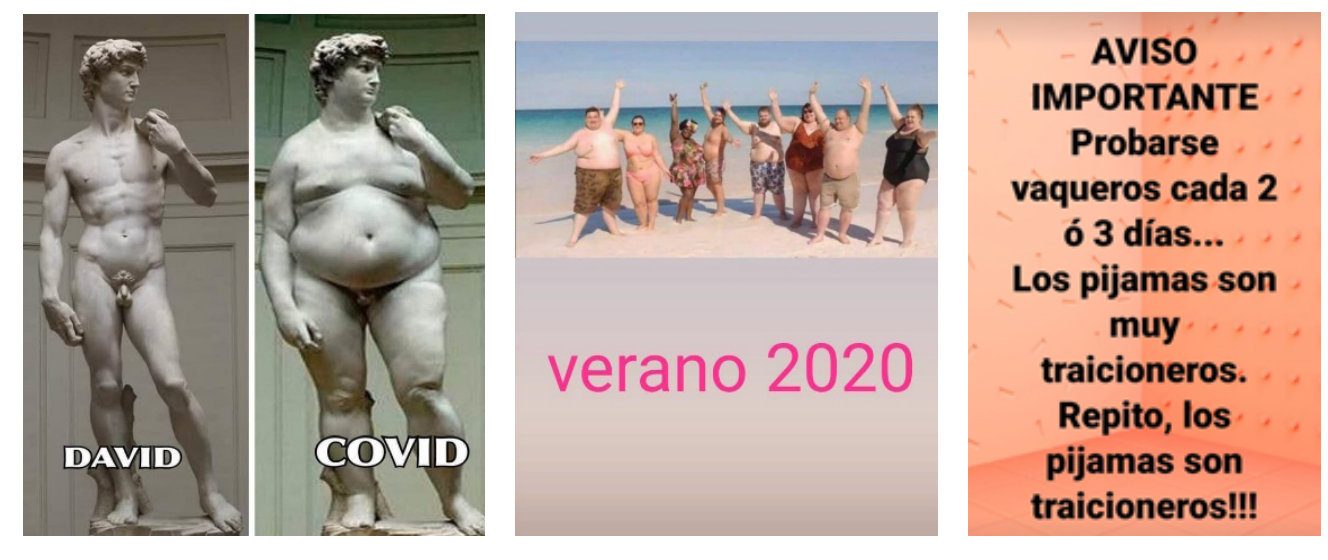

Fuente: Colección personal de la autora.

\section{Relaciones sociales mediadas}

En la medida que no se podía salir de casa excepto por causas justificadas, las relaciones interpersonales se vieron muy afectadas.

Una de las cosas que más pronto se recomendó a la población por parte de organismos sanitarios internacionales fue no estrecharse las manos al saludar. Besos y abrazos aun resultaban menos recomendables. Se dictaminó que una medida a seguir era el llamado distanciamiento o distancia social o distancia de seguridad. Primero la separación interpersonal se estableció en 1 metro; después se pasó al 1,5 metro e, incluso, a los 2 metros. En las aceras, a la entrada de tiendas, supermercados, sucursales 
Crónica de una pandemia: confinamiento en Castelló de la Plana, España Reis Lloría Adanero

bancarias, aparecieron unas líneas que marcaban la distancia de separación que se debía mantener mientras se hacía cola para acceder al establecimiento. En las puertas, ventanas y fachadas se colgaron carteles indicando el aforo máximo permitido en el interior del local. También en el interior señales en el suelo marcaban la distancia respecto a los mostradores o en las cajas (Figura 12). Todas estas medidas se han tomado para evitar, en la medida de lo posible, el contacto entre personas y, así, minimizar el riesgo de contagio.

Figura 12. Carteles y señalética indicando aforos y distancia de seguridad en diferentes establecimientos (supermercado, farmacia, sucursal bancaria, centro comercial)
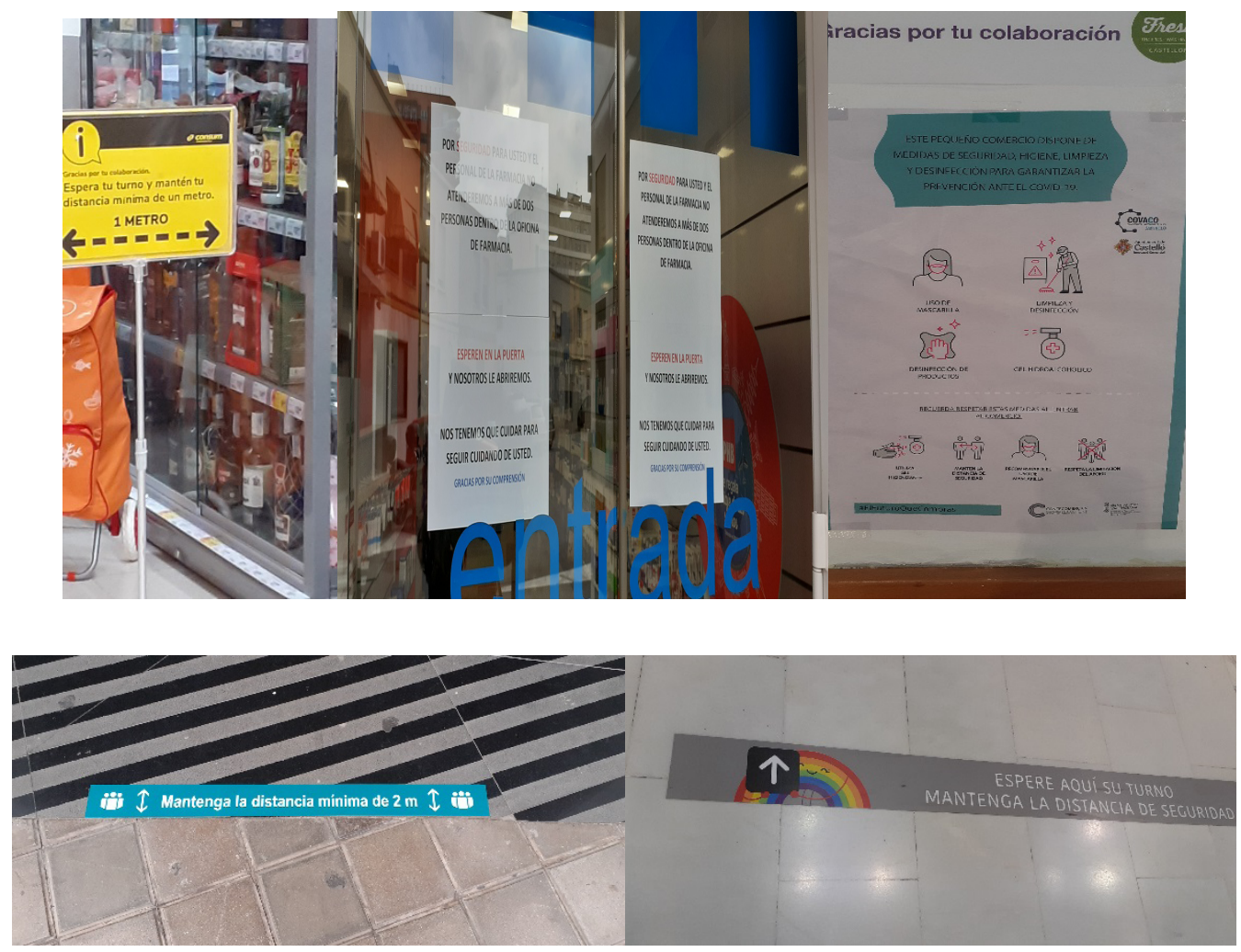

Fuente: Colección personal de la autora.

La declaración de estado de alarma ha tenido una repercusión total en las relaciones interpersonales. No solo no se podía salir de casa para ir a trabajar o estudiar, a la biblioteca o a ver un partido, 
tampoco se podía quedar para tomar algo o ir de visita: "hago alguna cosa de la casa de mantenimiento, que la tengo estupenda, que digo "La tengo estupenda y ahora no viene nadie" (Entrevista mujeres). Las comidas de los domingos con la familia estaban prohibidas mientras durara el estado de alarma. Hábitos cotidianos, rutinarios, se habían convertido en algo prohibido. Y es en este contexto que aparece la tecnología para suplir, en la medida de lo posible, el contacto físico, dando lugar a la aparición de "nuevos modos de interacción, sociabilidad y 'estar juntos' desde la distancia" (DÍEZ GARCÍA, BELLI y MÁRQUEZ, 2020, p. 760).

\begin{abstract}
No puedo ir a ver a mi madre que es muy mayor. Ella está bien, pero... Eso. Esa es la pega más grande, no poder salir, no poder ver a la gente, no poder hablar, da una poco de lástima. (Entrevista mujeres).
\end{abstract}

En todas las entrevistas se puede apreciar un único discurso: la tecnología no puede suplir las relaciones interpersonales directas, pero cuando la única alternativa es no mantener ningún tipo de contacto se convierten en un buen sustituto. De hecho, a finales de abril, WhatsApp amplió el número de personas que podían participar a la vez en una videollamada.

\begin{abstract}
Yo el relacionarte un poco con la gente, que al final es eso, sí, puedes hablar con la gente a través de una pantalla y tal, pero ahora lo que echas de menos realmente quedar con alguien y tomar algo, y... No sé, preguntarle a la cara que si está bien, si no, al final, por videollamada y tal está bien, pero es un poco más frío. (Entrevista jóvenes).
\end{abstract}

Sin embargo, estas relaciones mediadas por la tecnología también marcan diferencias entre los individuos, en la medida que no todas las personas disponen de teléfono inteligente que les permita mantener videollamadas, sobre todo (pero no únicamente) entre las personas mayores. En estos casos, la relación se limitaba 
Crónica de una pandemia: confinamiento en Castelló de la Plana, España Reis Lloría Adanero

a llamadas telefónicas diarias a diferentes miembros de la familia para mantener el contacto.

Yo con mi abuela me toca hablar también todos, todos, todos, los días. (Entrevista jóvenes).

Yo, por ejemplo, con mi madre solo, normalmente, por teléfono. El otro día le llevó mi hija la compra y aproveché y le hice una videollamada. Pero yo todos los días Ilamo a mi hija y le hago videollamada para ver a mis dos nietos. (Entrevista adultos).

Figura 13. Memes sobre las visitas a las personas mayores, el grupo más afectado durante la primera ola de la pandemia

\section{HASTA EL CUARENTA DE MAYO NO TE ACERQUES A UN YAYO}
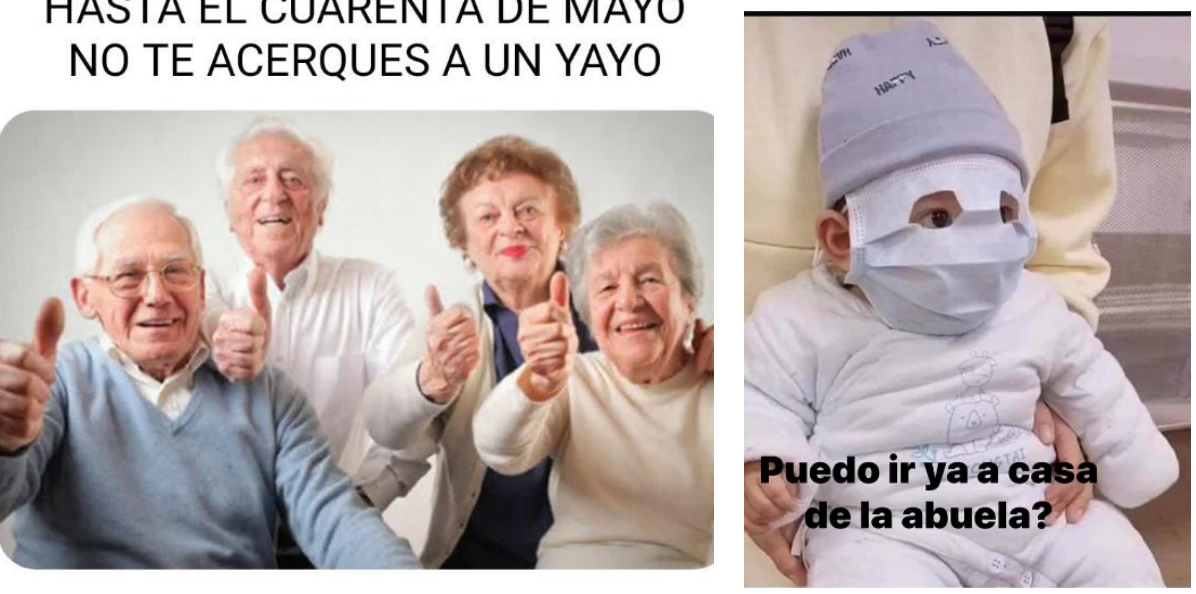

Fuente: Colección personal de la autora.

\section{Medios de comunicación y fatiga digital}

En las entrevistas apareció un tema recurrente relacionado con la información, tanto con el consumo de información, como con el exceso de información.

En general se puede decir que hay un consumo masivo de información, sobre todo en los primeros días de aparición de la enfermedad, la posterior declaración de pandemia por parte de la 
OMS y el decreto de estado de alarma del Gobierno de España. Se lee la prensa (principalmente digital), se escucha la radio, se mira la televisión, pero buscando contrastar la información a través de fuentes y medios con diferentes líneas editoriales (CATALÁNMATAMOROS, 2020). Se revisan las redes sociales, se comparte contenido.

\begin{abstract}
Yo, a mí me vais a decir friqui, pero yo no me fio de nadie y entonces leo, leo bastante, quiero decir que yo me leo igual un artículo del $A B C$, de la Razón, de El País, escucho la SER, escucho Onda Cero, eh, Mediterráneo, pero todo a través de redes sociales, pero normalmente me informo a través de tres o cuatro vías, porque es que es... Si hace años era mala la prensa, estos días, jvamos! es horrible, es horrible, no dicen... Van a un ritmo tan frenético que no, que no... La verdad es que no te informan, te gritan. (Entrevista adultos).
\end{abstract}

Esto se podría vincular a lo que afirma Rodríguez Alzueta (2020, p. 83) para quien el periodismo actual más que comunicar, dada la velocidad con que transmite la información, nos bombardea "con la realidad, con las noticias urgentes, de último momento, con alertas de todo tipo. Un periodismo, entonces, que tiene la capacidad probada de enloquecernos a todos y todas, de meterle más angustia a nuestras vidas angustiadas". Este exceso de información llevó a la OMS a declarar a mediados de febrero "la situación de infodemia para alertar a los países de la escalada de información falsa que también se tenía que combatir junto a la expansión del virus" (CATALÁN-MATAMOROS, 2020).

La crisis sanitaria provocada por la expansión de la COVID-19 ha acaparado la atención de medios de comunicación y redes sociales, tal como ponen de manifiesto Añel Rodríguez y Rodríguez Bilbao (2020, S299), para quienes se llegó a una situación de infoxicación por el exceso de información disponible, generada de forma continua por los medios de comunicación. Y cuando se alcanza ese nivel se limita el tiempo dedicado a la información y a las redes sociales. Ya no se pretende conocer hasta el último detalle, la última 
información o los últimos datos aparecidos. Se pone de manifiesto también la irrelevancia de parte de la información proporcionada, centrada sobre todo en datos, "un tsunami de cifras, conceptos, gráficos y normativas" (AÑEL RODRÍGUEZ y RODRÍGUEZ BILBAO, 2020, S299) y no tanto en las medidas concretas tomadas por el gobierno para paliar los efectos de la pandemia en diferentes sectores y grupos sociales.

Yo creo que también en cuanto a la información y todo eso desde el primer día hasta ahora ha evolucionado. Al principio fue un alud de noticias, de mirar periódicos, de mirar el Twitter, todas las redes sociales, a ver qué te decían y tal, porque había una ansiedad por saber qué estaba pasando porque que te digan “Todo el mundo a casa” y "¿Todo el mundo en casa?". (Entrevista mujeres).

Yo pienso que está bien que en este estado tan excepcional de la gente encerrada en casa, que está haciendo un gran esfuerzo, que sí que es preciso que, siendo que la ciudadanía estamos encerrados porque nos han dicho ellos que nos encerremos por nuestro bienestar y el bienestar del mundo mundial, vale, sí. Pero lo que pienso que es fatal es que salgan para no decir nada o decir chorradas o dar siempre números. Pero la cantidad de información de "tantos enfermos, tantos muertos, tantos en la UCl, no hay mascarillas...". Bueno, todo eso, vale, de cuando en cuando, pero sí que podrían tener, ya que es un gobierno y abarca todas les áreas, sí que podrían salir todos los días a dar cierta información... A lo mejor dos veces no, pero sí todos los días, por respeto a nosotros, a decir más o menos qué se está haciendo o qué no se está haciendo, la familias qué pueden hacer, indagar qué ayudas... No sé, hacer una cosa más social y más real. [...] Pero sí que tiene que salir el gobierno o representantes del gobierno a hablar todos los días a la ciudadanía que está encerrada y confinada en casa, sí, sí, por supuesto. (Entrevista mujeres). 
En este sentido coinciden con aquello que afirma Chechik (apud PICAZO SÁNCHEZ, FRUTOS TORRES y GUTIÉRREZ MARTíN, 2020, p. 360) -"en las crisis de salud pública no es tan fácil distinguir la línea que separa el informar del atemorizar, no es tan fácil saber cuándo la noticia ayuda, daña o alarma"- y comienza un proceso de selección de fuentes de información.

\begin{abstract}
Después has ido, un poco, rebuscando en los lugares donde te puedes informar. Hay todos los días canales que te van contando como las noticias más importantes, te van diciendo un poco eso, resúmenes... Nosotros hay grupos en los que te envían un poco la evolución cada día de los datos, por tanto yo he desconectado mucho de lo que dicen en la tele en ese sentido porque, además, es lo que decíais, parece un estado de alarma que te alarman más que otra cosa. Estar informado a mí me parece necesario. La información, la seleccionas. (Entrevista mujeres).
\end{abstract}

Se empieza a hablar de saturación, de fatiga digital, y comienza a buscarse otro tipo de actividades para llenar el tiempo hasta ese momento dedicado al coronavirus. Hay momentos en que incluso se desconectan los móviles o se dan de baja de grupos de Wasap para no recibir nuevos mensajes. También se hace una selección de los mensajes recibidos. Llega un momento en que los videos relacionados con el coronavirus se borran a los pocos segundos, sin acabar siquiera de verlos. Ya no se reenvían mensajes, sino que se eliminan.

\footnotetext{
Eh, a ver, yo es verdad que le estoy pillando un poco de manía al tema este. Pero no por nada. Porque yo durante la mañana no miro nada, y a las 4 cuando salgo puedo tener, no sé ¿150 Wasaps? (Entrevista adultos).
}

Yo estoy desbordada. Por ejemplo, yo ya ni envío Wasaps. (Entrevista mujeres). 
En el grupo de adolescentes aparece, además, una crítica a la programación televisiva, porque consideran que dedican demasiado tiempo a informar sobre el coronavirus cuando, en realidad, es poca la información nueva que pueden dar. Llegan a compararlo a las campañas electorales y a considerar que la programación no les permite buscar otras alternativas.

\begin{abstract}
Yo pienso que está bien que te informen de lo que está pasando, pero que te informen en cierta medida, porque es como cuando se están haciendo las elecciones, por ejemplo, que es que pones la televisión a la hora que la pongas, en cuatro o cinco programas están hablando de lo mismo todo el día y, además, la misma información constantemente. Y está bien que te informen, pues eso, de las nuevas informaciones o de lo que sea, pero es que la televisión abusa mucho de la información y se pueden tirar todo el día hablándote de lo mismo y no te dejan ver nada más, ¿sabes? Tú quieres ver alguna cosa interesante en la televisión, deportes o lo que sea, y no te dejan. (Entrevista adolescentes).
\end{abstract}

En la prensa escrita se puede apreciar la cantidad de páginas dedicadas a la información sobre la evolución de la pandemia: datos de personas enfermas, fallecidas, recuperadas. Las medidas tomadas para hacer frente a la enfermedad y a sus consecuencias. Las repercusiones en la economía en general y por sectores; en la cultura, suspensión de eventos de todo tipo. Congresos, conciertos, festivales, competiciones deportivas, fiestas locales, estrenos teatrales... En España, Europa, el mundo. Por continentes, por países, por ciudades. Todas las secciones del periódico tienen su foco puesto en la enfermedad y el coronavirus: economía, política, cultura, opinión, publicidad comercial e institucional -el propio RD No. 463/2020 (ESPAÑA, 2020a) establece en el artículo 19 la obligatoriedad de incluir los "mensajes, anuncios y comunicaciones que las autoridades competentes delegadas, así como las administraciones autonómicas y locales, consideren necesario emitir". 


\section{Aceptación del estado de alarma}

En este apartado trataré la aceptación del decreto de estado de alarma o, lo que es lo mismo, la respuesta de la población a las limitaciones de movilidad impuestas por el RD No. 463/2020 (ESPAÑA, 2020a) y sus prórrogas (ESPAÑA, 2020b, 2020c, 2020d, 2020e, 2020f, 2020g).

En este aspecto se puede decir que se ha aceptado la situación sin cuestionarse. Sí que es cierto que se han producido críticas y ha habido reacciones a las diferentes medidas que se han ido tomando pero, en general, se han seguido bastante a rajatabla todas las medidas que se han ido implementando.

El decreto entraba en vigor a las 00:00 horas del día 14 de marzo, sábado. Ese día por la mañana ya se podía apreciar una disminución del tránsito rodado por la ciudad. La gente que iba por la calle, menos numerosa que en una mañana de sábado y, por supuesto, menos que en un primer día de fiestas de la Magdalena, fiestas fundacionales de la localidad (hubieran empezado ese día pero fueron suspendidas, incluso antes de la publicación del decreto), se dirigía a aquellos lugares que estaban abiertos: supermercado, quiosco, estanco, verdulería. La mayor parte de establecimientos redujeron el horario de apertura al público, lo que sumado a las restricciones en el aforo, las colas para acceder al interior se convirtieron en habituales. El domingo por la mañana las calles y plazas estaban vacías; bares y cafeterías, cerrados; y el lunes los parques infantiles amanecieron precintados (figuras 14 y 15).

Figura 14. Castelló de la Plana
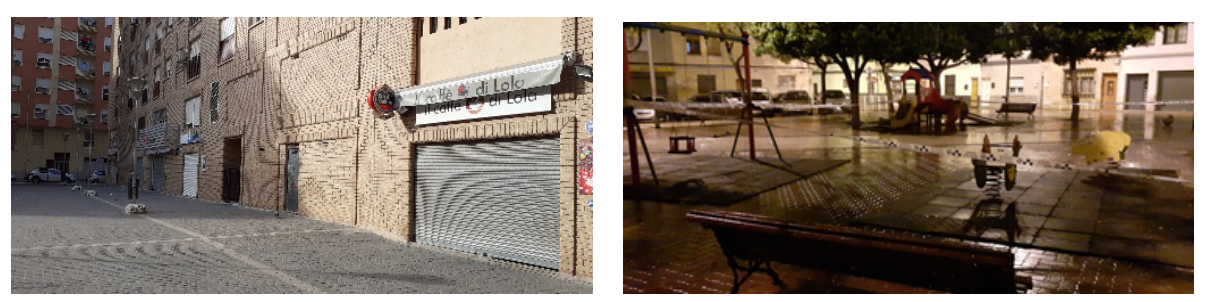

Fuente: Fotografías tomadas los días 14 y 16 de marzo de 2020. 
Figura 15. Avenida de València, Castelló de la Plana (izquierda), y Avenida Tarongers, València
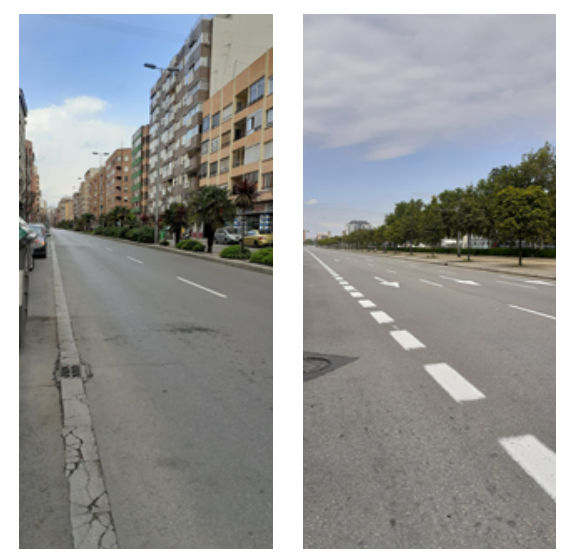

Fuente: Fotografías tomadas los días 26 de marzo y 23 de abril.

Y aquí somos bastante más obedientes que en el resto de España, porque yo salgo por la calle y no veo demasiada gente por las calles. Tú vas a cualquier otro sitio y hay mucha más gente que debería. Aquí la gente es muy respetuosa, tiene las medidas de seguridad entre... Entre consumidores en un súper, pues se llevan más a rajatabla que en otros sitios que, hala, el metro, el autobús y veinte en un coche. (Entrevista adultos).

Se sigue cargando pero no la cantidad de cuando se tiene la actividad normal. Entonces la gente lo está respetando bastante. Casi todos los almacenes y fábricas y actividades económicas del polígono están todos cerrados, o sea, que se ha respetado bastante y la gente se lo está tomando en serio. La verdad es que se lo está tomando bastante en serio. Yo me he quedado alucinado, yo pensaba que seríamos más rebeldes, la verdad. (Entrevista adultos).

En Francia les dejaban salir a hacer deporte, a correr y pasear; en Italia, también en un principio también les dejaban, luego lo cortaron. Aquí desde un principio se ha cortado y, sí, te fastidia, porque estás de, todo el santísimo día encerrado en casa, tantos días agobia, y mucho. Yo que salía a trabajar, luego venía a casa, 
ahora lo noto mucho, pero estamos haciéndolo, y te aguantarás y lo harás, y te molestará, pero el día que salgas... (Entrevista adultos).

Y es aquí donde aparecen las críticas a las decisiones tomadas por el gobierno. Estas críticas hacen referencia al momento en que se tomó la decisión de decretar el estado de alarma; a las primeras valoraciones que se hacían de la COVID-19, comparándola con una gripe; a la radicalidad de las medidas que suponía la declaración del estado de alarma. También se hacía una valoración de lo que suponía la paralización de la economía y qué debía primar, si la protección de las personas o la economía. Y otro aspecto que se resaltó en el grupo de mujeres fue la falta de información, más allá de los datos sobre la evolución de la enfermedad. Esta falta de información hacía referencia a las medidas concretas que se iban tomando en aspectos concretos (ayudas a autónomos y pequeñas y medianas empresas [PyMEs]; ayudas a personas en riesgo o situación de exclusión social) tanto a nivel estatal como autonómico.

Hablar sobre estas cosas son las que yo creo que importarían más que "Han habido tantos y el ejército somos todo uno y...". Bueno, serían más estas cosas. Es decir, este colectivo vamos a ver de qué manera y... Pero eso nada, o sea, por eso es un poco como que cada uno se salve a sí mismo y a los suyos y los demás, que se apañen, por mucho que dicen la solidaridad de la gente... Hombre, claro, tú no vas a dejar a nadie, pero, no, no... No, no, no me está gustando nada como se está llevando un tema tan importante como este. Y a parte es eso, que dices, bueno, estoy confinada yo, en mi caso, diez días, pero yo el lunes me iré allí a trabajar, sin medios... O sea, yo estoy poniéndome a mí que es lo que conozco directamente, no porque yo sea lo más importante, pero, como yo, mucha gente. Yo tengo mis hermanos trabajando uno en una fábrica, el otro en el juzgado y es lo mismo. El de la fábrica ahora también esta semana han empezado el tema... Pero han empezado el tema de teletrabajo 
y han empezado el tema de apartar a la gente de las fábricas, no porque "Ay, Ay, vamos a, cuidarlos", no, para tener gente de repuesto si caen enfermos los que están trabajando, y porque la producción se ha acabado. Se está acabando la producción. Y ahora sí, una vez la producción que tenían planeada y eso se ha acabado, ahora sí... No sé. Estas cosas se tendrían que explicar. ¿Por qué estamos trabajando? ¿No se puede parar la economía? Para mí no es respuesta "porque la economía no puede parar". No es respuesta. Que me expliquen "Mira, en una fábrica de tal no se puede parar porque tatatá, tatatá, tatatá" y tu podrías entender... Eso es lo que falta, la información de verdad del día a día de la calle, por sectores, por lo que sea. No. Ahora resulta que las peluquerías son de primera necesidad. Tienen que quedar abiertas. Nadie lo entiende. A los cinco minutos, no, se pueden cerrar. jHombre! Eso es lo que a mí más me enfada y me molesta. (Entrevista mujeres).

Otro aspecto en el que aparece un discurso muy crítico en este grupo de mujeres tenía que ver con el papel tan relevante otorgado a los cuerpos y fuerzas de seguridad del Estado (Policía Nacional, Guardia Civil y Fuerzas Armadas). Representantes de estos cuerpos aparecían en las ruedas de prensa que daban las autoridades competentes (Ministra de Sanidad, Ministra de Defensa, Ministro de Interior y Ministro de Transportes, Movilidad y Agenda Urbana) y en los que se informaba de la evolución de la pandemia (Figura 16). 


\section{Figura 16. Imagen de una rueda de prensa retransmitida por el Canal 3/245}

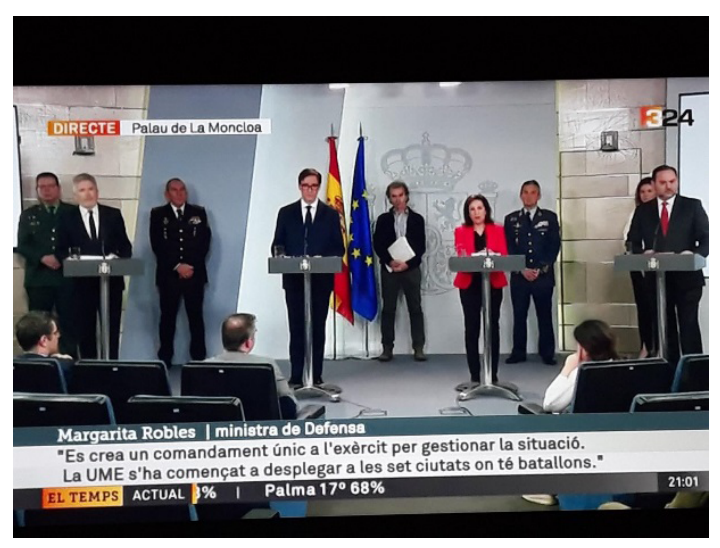

Fuente: Colección personal de la autora.

El ejército. O sea, a mí me duele ver al gobierno con tres militares detrás. A mí eso me hace daño. Yo, claro, yo me enciendo... ¿Qué otro país ha sacado a los militares a hacer declaraciones y todo eso? ¿Italia lo ha hecho? Ahí hay cuatro o cinco militares que a todos ellos los aglutina la ministra del ejército, por tanto, ella es la que tendría que hablar por todos, y no darles esa visibilidad. Pero eso dice mucho, el dar esa visibilidad dice mucho porque esa imagen... Somos una sociedad de imagen, ¿vale? Esa imagen dice mucho. Cuando te sale el Pedro Sánchez con dos militares al lado, mal vamos. Mal vamos.

Entrevistada: A mí no me gusta. Y supongo que a mucha gente tampoco.

Entrevistada: A mí no es que no me gusta. A mí me da miedo. (Entrevista mujeres).

También en algunos medios de comunicación aparecía esta crítica y se vinculaba en este caso al miedo, así como en algunos mensajes que circulaban por las redes sociales (Figura 17).

5 "Se crea un mando único en el ejército para gestionar la situación. La UME ha comenzado a desplegarse en las siete ciudades donde tiene batallones" (Margarita Robles, Ministra de Defensa). 
Figura 17. Mensaje en redes sociales ${ }^{6}$

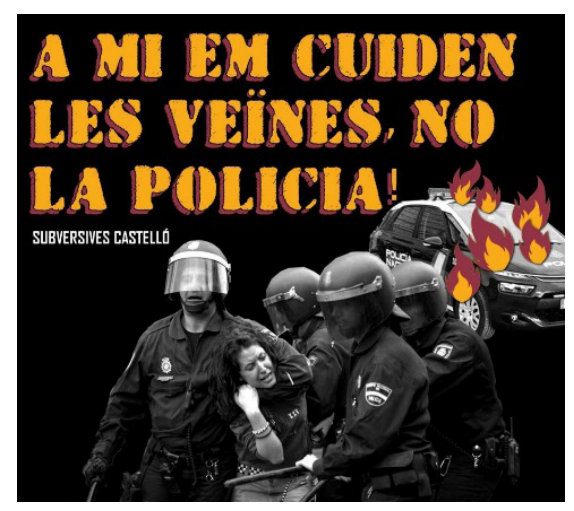

Fuente: Colección personal de la autora.

Esa opinión crítica contrastaba con el discurso en el grupo de adultos, donde se veía y se valoraba de una forma diametralmente opuesta la presencia de estos representantes del ejército en las ruedas de prensa.

Eso es una especie de reconocimiento a la faena... Me imagino que se hace por ese motivo. A la faena que están haciendo las fuerzas y cuerpos de seguridad del Estado. Que están ahí y que el público pueda ver que, efectivamente, detrás de los políticos está un cuerpo de seguridad para dar seguridad. Yo pienso que no tiene otro motivo que pueda salir. Efectivamente, esos datos, si son solo datos, podría darlos el ministro de interior o el ministro de defensa, no tendría que ser el portavoz de las fuerzas armadas, pero, bueno, yo no le veo más sentido al tema este. (Entrevista adultos).

En este sentido, se podría considerar que ambos discursos estarían dentro de los objetivos de la estrategia comunicativa desarrollada por el Gobierno de España para mostrar que "retiene el control de la situación, al menos en términos coercitivos, y no dudará en ejercer dicho control sobre la población, como atestiguan las abundantes informaciones sobre el número de multas o de detenidos por parte de las FCSE a lo largo del confinamiento" y,

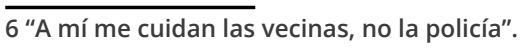


por otro, que "la crisis no sólo es seria, sino que, además de un problema sanitario, también constituye un reto para la seguridad de los españoles" $y$, en este sentido la presencia de representantes de las FCSE ofrecen esa sensación de seguridad y control de la situación a la población (LÓPEZ-GARCÍA, 2020). Aunque quizá, en el primer caso, influya también el papel que han tenido las fuerzas armadas en el desarrollo de la política en España (Golpe de Estado del 23F, de 1981).

Sobre el contenido del RD y las medidas que limitan el derecho a la libre circulación y el derecho de reunión no se plantean dudas, se acepta de manera acrítica y solo se cuestiona en el sentido de ser una molestia, pero necesaria para poder superar la pandemia.

La fecha del 8 de marzo, Día Internacional de la Mujer, y los actos que con este motivo se organizaron en las diferentes ciudades españolas, ha sido considerada, por parte de algunos partidos políticos y medios de comunicación, como responsable de haber aplazado el gobierno una semana la decisión de decretar el estado de alarma. Esta dicotomía puede apreciarse también en los discursos de las diferentes entrevistas realizadas. En el grupo de mujeres, pertenecientes a una asociación feminista de la localidad, la idea está bastante clara: se ha criminalizado, se ha hecho responsable de la propagación del virus a la celebración del 8M. En las otras dos entrevistas hay un discurso dominante: cuando una de las personas participantes argumenta que la declaración del estado de alarma se aplaza una semana porque para el gobierno es prioritario celebrar los actos conmemorativos del 8 de marzo, el resto del grupo argumenta que esos actos solo fueron unos de los muchos que se celebraron ese fin de semana, así como en los días sucesivos hasta que se publicó el decreto. En este sentido, también circuló por las redes sociales un mensaje en el que se ponía número a los actos celebrados el fin de semana del 7 y el 8 de marzo (Figura 18). 
Crónica de una pandemia: confinamiento en Castelló de la Plana, España

Figura 18. Uno de los mensajes en redes sociales que se reenviaron referente a las actividades realizadas el fin de semana del 8 de marzo

Luis Beltri Baudet $\nabla$

@luisbeltri

El fin semana del $7 / 8$ de marzo se

celebraron en España:

4000 partidos de futbol

680 de baloncesto

1000 de otros deportes

18000 misas

Congreso VOX

Cines, teatros, conciertos, centro

comerciales

Pero para algunos, el virus es por culpa de la celebración del Día de la

Mujer, el 8M

0:27-22 mar. 20 - Twitter for Android

4.417 Retweets 6.541 Me gusta

Fuente: Colección personal de la autora.

Y internet creo que está haciendo mucho bien, en este caso está haciendo bien, pero no todo el mundo sabe utilizarlo y, además, se ha de tener en cuenta que se puede hacer mucho daño, y ahora, por ejemplo, estás viendo todo el tema de, por ejemplo, lo que comentábamos el otro día por el Wasap de lo de la manifestación del 8 de marzo, ¿vale? ¿Qué pasa? Que la culpa la tienen las feministas, ¿no? (Entrevista mujeres).

Yo es que ahí tengo un pensamiento que igual es un poco radical pero es lo que pienso. Yo creo, por ejemplo, la manifestación del día 8, principalmente, esas manifestaciones yo creo que, directamente ya se tendrían que cancelar por toda la gente que se reunió y el impacto social que tuvieron. Entonces el gobierno no se atrevió a cancelar eso por el impacto mediático 
que tendría de cara a la sociedad que el gobierno cancele una manifestación, cara a la mujer, no se atrevieron, entonces, al no atreverse a hacer eso, les costó mucho más pues cancelar les fiestas de la Magdalena y de Fallas, que al final son 700 millones de euros lo que van a cancelar. Hasta que no se celebró una cosa, no cancelaron lo otro.

También estaba el Betis - Madrid que fue, creo, ¿no?, que también eran 40.000 personas. Es que esas cosas tampoco las cerraron. (Entrevista jóvenes).

Yo no creo que sea la economía lo que estaban pensando. Estaban pensando en un acto puntual...

Yo creo que estaban pensando en la economía y en...

Hicieron el acto ese y al día siguiente lo cerraron todo. Estaban llegando a ese día, tenían que llegar como fuese. Y lo permitieron todo.

Yo no creo que fuese por llegar a ese día porque no creo que ese día hubiese solamente una cosa puntual. Desde que se supo hasta que se cerró se han hecho muchas actividades y se han hecho muchas cosas con muchísima gente, en todas partes.

Claro, pero lo que no... Estoy diciendo...

De hecho, los colegios, los institutos, las universidades, siguieron funcionando exactamente igual y eran aglomeraciones de gente. El problema podía estar. Venía gente de Italia, venía gente de otros países, porque en la Universidad ha pasado, ha venido gente. $Y$ ese problema lo teníamos en todas partes. Yo creo que ha primado antes la economía que el esto, pensando que no podía llegar al extremo que ha llegado, a que llegara a colapsarse como se han colapsado.

Para nada. Yo estoy total... creo que lo que estaban pensando es en otra cosa, que estaban mirando su propio ombligo y el de los demás, no. En principio, no podían prohibir nada hasta este día porque si no lo que no pueden hacer es seleccionar "Tú, sí. Tú, no" por riesgo. Si han cancelado el Mobile, si han cancelado tal, coño, pero ¿qué no te lo están diciendo? ¿Qué no lo ves claro? Y ahora resulta que, claro, vienen de Italia, vienen partidos, vienen 
mítines, viene de todo. Había que esperar a ese día y al día siguiente cerrarlo porque si no, se perdía demasiado... No sé. Aquí lo dejo. (Entrevista adultos).

Hay que destacar que no fue hasta una semana después que se decretó el estado de alarma, cuando ya la OMS había decretado la pandemia, entre otras razones, por la falta de medidas tomadas por los distintos gobiernos del mundo.

\section{Confinamiento privilegiado}

Otro de los temas que aparecieron tiene que ver con las consecuencias de la pandemia. En las entrevistas a adultos y a mujeres se destaca que esta pandemia marcará un antes y un después que ha de provocar cambios. Lo que no se sabe es la dirección de este cambio.

Para Anta Félez (2020, p. 218), "la realidad Covid-19 es una metáfora de los humanos como forma vírica para el planeta", metáfora que también aparece en la entrevista a mujeres y en la que se responsabiliza a los seres humanos de la situación de la Tierra (Figura 19).

Yo también pienso que de aquí tienen que venir cambios, forzado por la situación y forzado también por las personas, la culpa también. Porque el planeta acabará tirándonos de verdad, porque lo que está claro que no le hacemos falta para nada.

Y encima nos lo estamos cargando.

Sí. Yo llegué a decirlo en algún sitio, el virus somos nosotros. El planeta se está deshaciendo, ya tiene bastantes anticuerpos como para deshacerse del virus que le molesta.

Las aguas cristalinas que hay en Venecia, la poca contaminación que se nota ahora desde el espacio. Está claro que somos nosotros los que estamos haciendo el empastre. (Entrevista mujeres). 
Figura 19. Meme que circuló por redes sociales

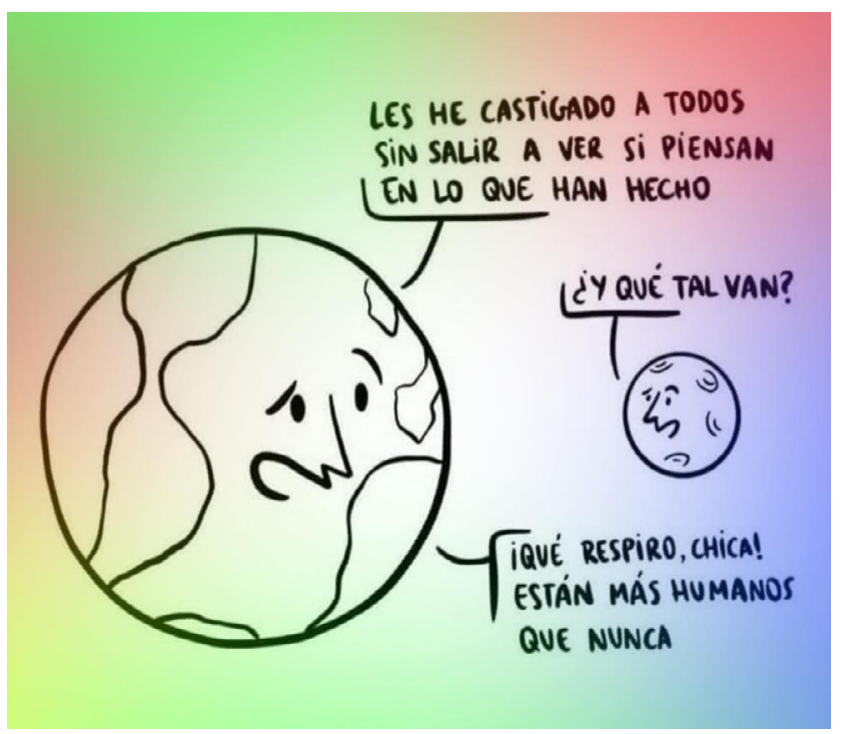

Fuente: Colección personal de la autora.

Sin embargo, tal como ponen de manifiesto López (2020, p. 78), la cuarentena es "un privilegio accesible a quienes tenemos lugar para encerrarnos y un salario, aunque no salgamos a trabajar. Pero a la vera de eso están los millones de personas que viven en casas precarias, cuyos ingresos provienen de la economía popular", en la medida que "no todos podemos tramitar la cuarentena con la misma heladera, los mismos ahorros, el mismo reaseguro" (RODRÍGUEZ ALZUETA, 2020, p. 85). Para BUTLER (2020), no es el virus quien discrimina, sino que "la desigualdad social y económica asegurará que el virus discrimine". En este sentido, este grupo de mujeres son conscientes de encontrarse en una situación de privilegio, por la situación familiar y económica y por las características de sus viviendas, con una especial mención a las mujeres víctimas de violencia de género que han tenido que confinarse con sus maltratadores, las personas mayores, que viven solas y necesitan ayuda para hacer cualquier tipo de gestión, y aquellas cuyos ingresos dependen de la economía sumergida y se han visto confinadas, sin poder trabajar y sin alternativas (Figura 20). 
Nosotras estamos hablando de sacrificarnos y vivimos muy a gusto. Pero cuánta gente está ahora actualmente, ¿no?, en casas que van... Hay lo menos 10 dentro de una casa y no tienen absolutamente ningún recurso, ni un sueldo porque además han perdido, actualmente, ahora mismo, de ayer a hoy, han perdido la faena que tenían en su casa, porque iban a limpiar una casa sin contrato. $Y$ ahí, ¿qué? ¿Está la gente? ¿Están los militares, el gobierno? ¿Está por esas personas? Porque nosotras hablamos desde nuestro privilegio. No lo estoy pasando mal, estoy pasando un mal trago y ya está. (Entrevista mujeres).

Yo le he dado muchas vueltas, no me lo puedo quitar de la cabeza, la gente que vive en pisos muy pequeños, o la gente... ya pienso incluso en la gente que ha cogido la terraza y se la ha acristalado y a duras penas si tiene un par de ventanas para dar a la calle y en las mujeres maltratadas, que están encerradas con los maltratadores, cuando pienso en esto, a mí los demonios se me arrebatan. Porque pienso que hay gente que está pasándolo muy, muy, muy mal, muy mal, y, que dentro de todo, yo tengo una suerte fantástica. (Entrevista mujeres).

No, hombre, lo que está claro es que desde nuestra posición se ve todo de una manera, no digo irreal, porque también es real nuestra posición y nuestra... es real, es realidad, pero sí que es de verdad que lo que es la realidad dura nosotras no la vemos, la podemos ver algo en nuestros trabajos o en los colectivos que estamos en algún momento cerca. (Entrevista mujeres). 
Crónica de una pandemia: confinamiento en Castelló de la Plana, España Reis Lloría Adanero

Figura 20. Mensaje en redes sociales conminando a continuar pagando salarios

\#CuidaAQuienTeCuida

CUIDA A TUS TRABAJADORAS DOMÉSTICAS, CUIDADORAS, INTERNAS, LIMPIADORAS... PERMITE QUE SE QUEDEN EN SU CASA, CON SU SUELDO

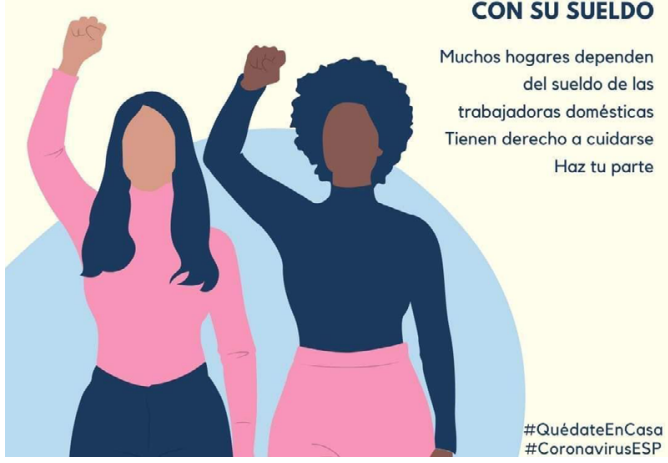

Fuente: Colección personal de la autora.

En este sentido coinciden con De Sousa Santos (2020, p. 45), quien considera que las medidas que ha propuesto la OMS para superar la pandemia (lavarse las manos a menudo con jabón, geles hidroalcohólicos, distancia de seguridad, confinamiento, trabajar desde casa) son difíciles de seguir por todas aquellas personas que forman lo que llama el Sur de la cuarentena, "grupos para los que la cuarentena es particularmente difícil [...] que tienen en común una vulnerabilidad especial que precede a la cuarentena y que se agrava con ella". Estos grupos estarían formados por mujeres, trabajadores precarizados e informales, vendedores ambulantes, personas sin hogar o que viven en la calle, residentes de las periferias pobres de las ciudades (favelas, asentamientos informales, s/ums...), internos en campos de internamiento para refugiados, inmigrantes indocumentados y poblaciones desplazadas internamente, discapacitados, ancianos. En este sentido, "el sur no designa un espacio geográfico sino un espaciotiempo político, social y cultural" (DE SOUSA SANTOS, 2020, p. 45). Entre los vendedores ambulantes incluye "las personas uberizadas de la economía informal que entregan alimentos y paquetes a domicilio. Ellos garantizan la cuarentena de muchos pero no 
Crónica de una pandemia: confinamiento en Castelló de la Plana, España

pueden protegerse. Su 'negocio' aumentará tanto como el riesgo al que se exponen" (DE SOUSA SANTOS, 2020, p. 45). Un ejemplo de esto último se ha visto en la localidad en la que resido, donde se ha producido un incremento de repartidores de comida a domicilio ${ }^{7}$. En la cita que viene a continuación se menciona precisamente este aspecto del riesgo asumido por los transportistas y repartidores para servir los pedidos que se hacen en línea.

Eso le pasa en el trabajo a mi marido. En principio, no le van a hacer un ERTE, porque la gente se ha vuelto loca comprando por internet. Él trabaja en una tienda online de muebles, y faena tienen igual, lo mismo. Es una empresa nacional. Entonces, viene gente de Madrid, de Barcelona y como se van contagiando cada vez hay menos transportistas y tarda más el mueble en llegar. Pero faena ahora mismo tienen la misma cantidad. Lo que están es pendientes, como el setenta por ciento de trabajo va por Amazon, que si Amazon cierra, ellos tendrán que cerrar, y entonces sí que tendrán que hacer un ERTE y están pendientes de eso. Pero ¿faena? Ya os digo, las empresas online están flipando. (Entrevista jóvenes).

Y en este sentido, De Sousa Santos (2020, p. 58-59) también destaca que si la cuarentena hace más visibles estas situaciones de desigualdad, al mismo tiempo "también refuerza la injusticia, la discriminación, la exclusión social y el sufrimiento inmerecido que provocan".

\section{Conclusiones}

El estado de alarma decretado por el Gobierno de España para contener la expansión de la COVID-19 supuso un cambio radical en la vida de la población.

\footnotetext{
7 La calle en la que resido cuenta con 2 restaurantes doner kebab, 1 restaurante indio, 3 pizzerías, 1 restaurante japonés, 1 restaurante chino y 1 casa de comida para llevar. En el momento en que se levantó un poco la cuarentena, empezaron a aparecer repartidores, hombres y mujeres, (en bicicleta, patinete eléctrico, moto) que hacían cola en estos establecimientos para recoger los pedidos. Nunca antes se habían visto tantos.
} 
El confinamiento se ha vivido de manera diferente según la edad y la situación laboral y económica de cada individuo. Entre los grupos de adultos es en el de mujeres, por su mayor compromiso político, donde se destaca que la pandemia ha exacerbado las desigualdades existentes en las sociedad actual, en la medida que no es lo mismo estar trabajando en el sector informal de la economía, porque el estado de alarma ha hecho que la mayor parte de estos empleos se pierdan, que formar parte de una clase media, que trabaja en el sector formal y que no ha dejado de percibir su salario como sería su caso (funcionarias la mayoría) o ha podido acogerse a algún tipo de ayuda otorgada por el gobierno del Estado o las comunidades autónomas. De ahí que hablen de situación privilegiada.

En cuanto a la aceptación del estado de alarma, como hecho que ha cambiado la vida cotidiana, se ha producido sin críticas, sin cuestionarse, excepto en el grupo de adolescentes. Este grupo es el que muestra mayor reticencia, ya que es el grupo que menores posibilidades tenía de salir del domicilio, en la medida que ninguna de sus actividades habituales estaban permitidas. Los grupos de adultos, sin embargo, lo han aceptado como la única vía para poder contener la expansión de la enfermedad, con vistas al bien común. Esto me lleva a considerar que la gran cantidad de datos relativos a número de personas enfermas y fallecidas, tasas de ocupación de camas en hospitales, la falta de recursos y personal o el posible colapso de los servicios sanitarios que se han ido ofreciendo cada día en todos los medios de comunicación y por redes sociales han contribuido a fomentar ese miedo y a que se aceptara de mejor forma el confinamiento.

Las alteraciones en la vida cotidiana se han visto en todos los ámbitos. Ha hecho su aparición de una forma rápida el teletrabajo, en aquellos sectores o actividades susceptibles de transformarse, y en la educación, que pasó de ser presencial a ser en línea sin solución de continuidad. Y es en el teletrabajo donde aparece la crítica más importante, también destacada en el grupo de mujeres, por la falta de medios, aportados en su mayoría por las propias 
empleadas y empleados, y por considerarla una estrategia laboral implementada por causa de fuerza mayor que se mantendrá en el tiempo, por los cambios que se pueden producir en las relaciones laborales, en un país donde la precariedad es muy alta. Al mismo tiempo, se muestra cierto temor en la reincorporación al trabajo por miedo al contagio por la falta de medidas de seguridad e higiene (mamparas, geles, etc.) cuando no han podido acogerse al teletrabajo, como se pone de manifiesto en el grupo de mujeres y en el de adolescentes.

Las relaciones sociales se han visto transformadas absolutamente. El estado de alarma ha impedido mantener cualquier tipo de relación directa con todas aquellas personas que no formaban parte del núcleo de convivencia, por lo que se han transformado en una comunicación mediada por la tecnología, considerada más fría por parte del grupo de jóvenes, aunque necesarias para mantener el contacto, $y$, al mismo tiempo, se ha puesto de manifiesto la brecha digital existente entre las diferentes generaciones.

En los distintos grupos se ha hablado de fatiga digital, por un exceso de exposición a las redes sociales y medios de comunicación. Y aquí se puede apreciar una doble valoración de la información. Por un lado, se considera que hay un exceso de información, queja expresada especialmente en el grupo de adolescentes, pero también en el de mujeres, porque, por otro lado, atendiendo al contenido de esa información, se considera que resulta repetitiva y centrada exclusivamente en los datos, cuando la información que el gobierno debería transmitir a la ciudadanía debería referirse a las medidas políticas concretas en los diferentes ámbitos, tomadas para paliar los efectos de la pandemia. La saturación de información hace que se empiece a mantener otro tipo de relación con las redes sociales.

Por último, la mayor controversia la genera el momento elegido por el gobierno del Estado para decretar el estado de alarma. Y la misma controversia que ha aparecido en las entrevistas grupales es reflejo de la que se produjo en los medios de comunicación y entre los diferentes partidos políticos, cuando se vinculó la fecha 
de la declaración de estado de alarma a la realización de los actos organizados con motivo del 8M.

Paraacabar, lo que más me ha sorprendido en esta investigación ha sido la aceptación del decreto de estado de alarma sin cuestionarlo, sin entrar a valorar qué implicaba el confinamiento en tanto que restricción de los derechos de movimiento y reunión. El temor al contagio, tan bien gestionado en el aluvión de datos sobre personas afectadas, ha sido interiorizado y estar encerrados en casa es una muestra de solidaridad para con los demás.

\section{Referencias}

AÑEL RODRÍGUEZ, Rosa María; RODRíGUEZ BILBAO, Emilio. La comunicación en la crisis del COVID-19: relato único, marco épico y relatos ausentes. Revista Española de Comunicación en Salud, Madrid, Suplemento 1, S293-S303, 2020.

ANTA FÉLEZ, José Luis. Acontecimiento y control social. El Régimen de confinamiento durante el COVID-19. Perifèria, Revista de Recerca i Formació en Antropologia, Barcelona, v. 25, n. 2, p. 216-226, 2020.

\section{BUTLER, Judith. Judith Butler sobre coronavirus y poder:} de Trump a la enfermedad de la desigualdad. 27 mar. 2020. Disponible en: https://www.lavaca.org/notas/el-capitalismo-tiene-sus-limites-la-mirada-de-judith-butler-sobre-el-coronavirus/. Accedido: 29 sep. 2020.

CATALÁN-MATAMOROS, Daniel. La comunicación sobre la pandemia del COVID-19 en la era digital: manipulación informativa, fake news y redes sociales. Revista Española de Comunicación en Salud, Madrid, Suplemento 1, S5-S8, 2020.

DE SOUSA SANTOS, Boaventura. La cruel pedagogía del virus. Buenos Aires: CLACSO, 2020. 
DÍEZ GARCÍA, Ruben.; BELLI, Simone.; MÁRQUEZ, Israel V. La COVID-19, pantallas y reflexividad social. Cómo el brote de un patógeno está afectando nuestra cotidianidad. Revista Española de Sociología, Madrid, v. 29, n. 3, p. 759-768, 2020.

ESPAÑA. Real Decreto No. 463/2020, de 14 de marzo. Declara el Estado de Alarma para la gestión de la situación de crisis sanitaria ocasionada por el COVID-19. 14 mar. 2020a. Disponible en: https://www.boe.es/eli/es/rd/2020/03/14/463. Accedido: 29 sep. 2020.

ESPAÑA. Real Decreto No. 476/2020, de 27 de marzo. Prorroga el Estado de Alarma declarado por el Real Decreto No. 463/2020, de 14 de marzo. 27 mar. 2020b. Disponible en: https://www.boe. es/eli/es/rd/2020/03/27/476/con. Accedido: 29 sep. 2020.

ESPAÑA. Real Decreto No. 487/2020, de 11 de abril. Prórroga del Estado de Alarma declarado por el Real Decreto No. 463/2020, de 14 de marzo. 11 abr. 2020c. Disponible en: https://www.boe. es/boe/dias/2020/04/11/pdfs/BOE-A-2020-4413.pdf. Accedido: 7 oct. 2020.

ESPAÑA. Real Decreto No. 492/2020, de 24 de abril. Prorroga el Estado de Alarma declarado por el Real Decreto No. 463/2020, de 14 de marzo. 24 abr. 2020d. Disponible en: https://boe.es/buscar/ act.php?id=BOE-A-2020-4652. Accedido: 7 oct. 2020.

ESPAÑA. Real Decreto No. 514/2020, de 8 de mayo. Prorroga el Estado de Alarma declarado por el Real Decreto No. 463/2020, de 14 de marzo. 8 mayo 2020e. Disponible en: https://boe.es/buscar/ act.php?id=BOE-A-2020-4902. Accedido: 7 oct. 2020.

ESPAÑA. Real Decreto No. 537/2020, de 22 de mayo. Prorroga el Estado de Alarma declarado por el Real Decreto No. 463/2020, de 14 de marzo. 22 mayo 2020f. Disponible en: https://boe.es/ buscar/act.php?id=BOE-A-2020-5243. Accedido: 7 oct. 2020.

ESPAÑA. Real Decreto No. 555/2020, de 5 de junio. Prorroga el Estado de Alarma declarado por el Real Decreto No. 463/2020, de 
14 de marzo. 5 jun. 2020g. Disponible en: https://boe.es/buscar/ act.php?id=BOE-A-2020-5767. Accedido: 7 oct. 2020.

FONTANA SIERRA, Laura. Pandemia y rearticulación de las relaciones sociales. Perifèria, Revista de Recerca i Formació en Antropologia, Barcelona, v. 25, n. 2, p. 101-114, 2020.

GENERALITAT VALENCIANA. Educación y Hacienda aumentan a $\mathbf{1 4 . 0 0 0}$ las tabletas con Internet para llegar al alumnado más vulnerable de Primaria y de centros concertados. 4 abr. 2020. Disponible en: http://www.ceice.gva.es/es/inicio/area_de_prensa/ not_detalle_area_prensa?id=853379. Accedido: 29 sep. 2020.

LÓPEZ, María Pía. La vida en cuestión. In: SVAMPA, Maristella et al. La fiebre: pensamiento contemporáneo en tiempos de pandemias. Buenos Aires: Aislamiento Social Preventivo y Obligatorio, 2020. p. 69-77.

LÓPEZ-GARCÍA, Guillermo. Vigilar y castigar: el papel de militares, policías y guardias civiles en la comunicación. El Profesional de la Información, Madrid, v. 29, n. 3, e290311, 2020.

\section{8}

MINISTERIO DE DERECHOS SOCIALES Y AGENDA 2030. Preguntas frecuentes sobre las medidas sociales contra el coronavirus. 2020. Disponible en: https://www.mscbs.gob.es/ssi/portada/docs/ PREGUNTAS_FRECUENTES_SOBRE_LAS_MEDIDAS_SOCIALES_ CONTRA_EL_CORONAVIRUS.pdf. Accedido: 29 sep. 2020.

PICAZO SÁNCHEZ, Laura; FRUTOS TORRES, Belinda de; GUTIÉRREZ MARTÍN, Alfonso. La COVID-19 en la prensa española. Encuadres de alarma y tranquilidad en las portadas de El País, El Mundo y La Vanguardia. Revista de Comunicación y Salud, Madrid, v. 10, n. 2, p. 355-384, 2020.

RODRÍGUEZ ALZUETA, Esteban. Las trampas de la unidad. In: SVAMPA, Maristella et al. La fiebre: pensamiento contemporáneo en tiempos de pandemias. Buenos Aires: Aislamiento Social Preventivo y Obligatorio, 2020. p. 79-88. 
